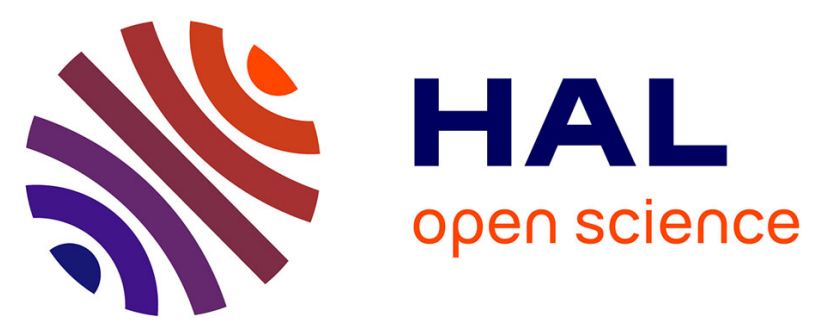

\title{
Effect of mycorrhizal inoculation on metal accumulation by poplar leaves at phytomanaged sites
}

Phonethip Phanthavongsa, Michel M. Chalot, Arnaud Papin, Laurence Lacercat-Didier, Sébastien Roy, Damien Blaudez, Valérie Bert

\section{To cite this version:}

Phonethip Phanthavongsa, Michel M. Chalot, Arnaud Papin, Laurence Lacercat-Didier, Sébastien Roy, et al.. Effect of mycorrhizal inoculation on metal accumulation by poplar leaves at phytomanaged sites. Environmental and Experimental Botany, 2017, 143, pp.72 - 81. 10.1016/j.envexpbot.2017.08.012 . hal-01693247

\section{HAL Id: hal-01693247 https://hal.science/hal-01693247}

Submitted on 31 Aug 2018

HAL is a multi-disciplinary open access archive for the deposit and dissemination of scientific research documents, whether they are published or not. The documents may come from teaching and research institutions in France or abroad, or from public or private research centers.
L'archive ouverte pluridisciplinaire $\mathbf{H A L}$, est destinée au dépôt et à la diffusion de documents scientifiques de niveau recherche, publiés ou non, émanant des établissements d'enseignement et de recherche français ou étrangers, des laboratoires publics ou privés. 


\section{Effect of mycorrhizal inoculation on metal accumulation by poplar leaves at phytomanaged sites}

\section{Phonethip Phanthavongsa ${ }^{a, b}$, Michel Chalot ${ }^{b, c}$, Arnaud Papin ${ }^{d}$, Laurence Lacercat- Didier $^{\text {c }}$, Sébastien Roy ${ }^{\mathrm{e}}$, Damien Blaudez ${ }^{\mathrm{f}}$, Valérie Bert ${ }^{\text {a }}$}

${ }^{\text {a }}$ INERIS, Clean and Sustainable Technologies and Processes Unit, DRC/RISK, Parc Technologique Alata, BP2, 60550 Verneuil-en-Halatte, France

${ }^{\mathrm{b}}$ Université de Bourgogne Franche-Comté, UMR CNRS 6249 Laboratoire Chronoenvironnement, Pôle Universitaire du Pays de Montbéliard, 4 place Tharradin, BP 71427, 25211 Montbéliard, France

${ }^{\mathrm{c}}$ Université de Lorraine, Faculté des Sciences et Technologies, BP 70239, 54506 Vandœuvrelès-Nancy, France

${ }^{\mathrm{d}}$ INERIS, Analytical Ressources Unit, DRC/RISK, Parc Technologique Alata, BP2, 60550 Verneuil-en-Halatte, France

${ }^{\mathrm{e}}$ Agronutrition SA, 436 rue Pierre et Marie Curie, 31670 Labège, France

${ }^{\mathrm{f}}$ Université de Lorraine, UMR CNRS 7360 Laboratoire Interdisciplinaire des Environnements Continentaux, Faculté des Sciences et Technologies, BP 70239, 54506 Vandœuvre-lès-Nancy, France

\section{Corresponding author: Valérie Bert}

Valerie.bert@ineris.fr

INERIS, Clean and Sustainable Technologies and Processes Unit, DRC/RISK, Parc Technologique Alata, BP2, 60550 Verneuil-en-Halatte, France

\section{Highlights}

- $\quad \mathrm{Cd}$ and $\mathrm{Zn}$ concentrations in leaves exceeded physiological values

- PTE accumulation in poplar leaves was enhanced in more fertile soils 
- Mycorrhizal inoculation limited $\mathrm{Zn}, \mathrm{Cu}, \mathrm{Pb}$ and $\mathrm{Cr}$ accumulation in Skado leaves

- The inoculum was effective in highly contaminated soils

\begin{abstract}
Phytotechnologies for the management of lands contaminated with potentially toxic elements (PTEs) are considered as gentle alternatives to conventional remediation techniques. During the last few years, phytotechnologies have progressively shifted to phytomanagement, a concept that includes the valorization of the plant biomass produced on the contaminated site. This study aimed at evaluating the mid-term effect of ecto- and endomycorrhizal inoculation on the reduction of PTE mobility in soils and foliar accumulation by two poplar clones, Skado (Populus trichocarpa $x$ P. maximowiczii) and I-214 (P. deltoides $x$ P. nigra), dedicated to bioenergy purposes. The effects of inoculation were investigated in two large scale trials of 1 ha each. Poplars grown on highly contaminated soils accumulated excessive $\mathrm{Cd}$ and $\mathrm{Zn}$ in leaves compared with those planted on less contaminated soils, and the I-214 clone generally accumulated less PTEs than the Skado clone. Interestingly, the filtering capacity of mycorrhizal fungi was significant for $\mathrm{Zn}, \mathrm{Cu}, \mathrm{Pb}$ and $\mathrm{Cr}$ in Skado leaves only at the most contaminated areas after two growing seasons. These foliar concentrations were not correlated with $\mathrm{Ca}\left(\mathrm{NO}_{3}\right)_{2}$-extractable concentrations in soils, suggesting that mycorrhizal fungi limited PTE translocation from roots to leaves without impacting PTE mobility in soils. Therefore, the reduction of PTE accumulation in poplar leaves may be optimized by selecting appropriate combinations of cultivars and inocula at specific PTE levels and soil conditions. Because $\mathrm{Cd}$ and $\mathrm{Zn}$ may pose a risk after leaf abscission and wood harvest, further research is needed to efficiently reduce $\mathrm{Cd}$ and $\mathrm{Zn}$ concentrations in poplar tissues. Otherwise, the phytomanagement of metal contaminated sites with poplars should include options to safely manage both leaves and wood.
\end{abstract}

Keywords: mycorrhizal inoculation, phytostabilization, phytomanagement, Skado, I-214, trace elements 


\section{Introduction}

Since the 1990s, phytotechnologies are considered as an alternative to conventional remediation techniques (Salt et al., 1995; Vangronsveld et al., 2009). They have been applied to manage sites contaminated by potentially toxic elements (PTEs), which may deeply alter the environment and human health through the food chain (Järup, 2003; Kabata-Pendias, 2004). The last few years, phytotechnologies have progressively shifted to phytomanagement, a concept which included the valorization of the plant biomass produced on contaminated sites, to generate economic revenue (Evangelou and Deram, 2014). Although some valorization options have been deeply investigated and provided opportunities for such biomass (Bert et al., 2017; Chalot et al., 2012; Delplanque et al., 2013) phytomanagement is still scarcely applied in European countries and suffer from lack of field experiment feedbacks (Cundy et al., 2013).

Among the different phytotechnologies that can be applied to large contaminated areas, aided phytostabilization aims at using plants and biological or chemical amendments to retain pollutants in soils via root uptake, chelation or reduction (Mench et al., 2010). Fast growing tree species such as willows and poplars have been suggested as suitable for phytostabilization due to their high biomass production and their wide-spreading root system which can protect soil surface from erosion (Pulford and Watson, 2003). In addition, this strategy is based on the selection of the less accumulating cultivars to avoid or limit the transfer of the contaminants in the food chain and in the end-products after wood conversion process (Bert et al., 2017). Short rotation coppice (SRC) of inoculated poplars for bioenergy production in metal contaminated lands has been proposed as a phytomanagement strategy that may control environmental impacts and increase economic opportunities (Chalot et al., 2012).

Biological amendments such as mycorrhizal fungi have been for long envisaged as relevant microorganisms to help for restoration or improvement of derelict soils. Indeed, when associated with endomycorrhizal fungi, poplars exhibit enhanced tolerance to biotic and abiotic stress, with better growth and higher biomass production (Cicatelli et al., 2014). When plants are introduced for site restoration, the in-situ success of these plants will likely be depending on the recruitment of appropriate rhizosphere microorganisms from their new environment (Bell et al., 2015). In a recent study, we demonstrated that the occurrence and persistence of ectomycorrhizal symbionts were greatly driven by site characteristics (Foulon et al., 2016). Mycorrhizal inoculation at plantation may be thus necessary, either to improve 
mycorrhizal infection when the local symbionts are lacking, or to improve the competitiveness and tolerance of the mycorrhizal microbiome.

Most studies to date have proposed adequate tree/ecto- or endo-mycorrhizal combinations to either increase (Cicatelli et al., 2010; Sell et al., 2005) or decrease (Bojarczuk and Kieliszewska-Rokicka, 2010; Mrnka et al., 2012) PTE transfer from soil to aboveground plant tissues. Colpaert et al. (2011) pointed out the fact that most of these studies were based solely on pots/greenhouse experiments and field studies remained scarce. It is admitted that extrapolation from laboratory/greenhouse to field is not reliable, since soil-plant transfer of PTEs is a complex process governed by geochemical, climatic, biological and anthropogenic factors (Kabata-Pendias, 2004). These data nevertheless highlighted the filtering potential of some mycorrhizal fungi, in some specific conditions such as elevated concentrations of PTEs. This filter function is an interesting feature of mycorrhizal fungi, when the phytomanagement approach aims at valorizing the aboveground biomass to increase economic opportunities. As metal concentrations in wood are generally lower than those in leaves (Laureysens et al., 2004; Madejón et al., 2004; Robinson et al., 2000), the determination of leaf metal concentrations is commonly used as non-destructive method to assess poplar metal uptake.

In a recent paper, we demonstrated that ecto- and endomycorrhizal inoculation significantly increased poplar biomass production at phytomanaged sites (Ciadamidaro et al., 2017). In the present study, we hypothesized that the inoculation of poplars with these mycorrhizal fungi would reduce the transfer of PTEs from soil to the aboveground parts of the trees. The aim of this paper was to investigate, at field scale, the impact of mycorrhizal inoculation on the foliar accumulation of trace and major elements of two hybrid poplars Skado (Populus trichocarpa $x$ P. maximowiczii) and I-214 (P. deltoides $x$ P. nigra), grown at two different PTE-contaminated sites. The paper discusses the results from an applied point of view and provides recommendations for phytomanagement improvement.

\section{Materials and Methods}

\subsection{Site description}

Two field sites of 1 hectare each located in Pierrelaye (Île-de-France, France, $49^{\circ} 01^{\prime} 47.4^{\prime \prime} \mathrm{N} 2^{\circ} 10^{\prime 29.2}$ "E) and Fresnes-sur-Escaut (Hauts-de-France, France, 50²5'47.9"N $\left.3^{\circ} 35^{\prime} 07.8^{\prime \prime E}\right)$ were set up in February and April 2011, respectively. The Pierrelaye site was formerly used for market gardening and was irrigated with raw wastewater in the end of the 
$19^{\text {th }}$ century, for more than 100 years. These inputs led to an enrichment of PTEs such as Zn, $\mathrm{Pb}, \mathrm{Cd}$ and $\mathrm{Cu}$ in top surface (Lamy et al., 2006). The Fresnes-sur-Escaut site (Fresnes further in the text) was established on a metal contaminated dredged sediment landfill site, operating between 1978 and 1989. The two sites were under the same temperate climatic conditions, with average annual temperatures of $10.8-10.9{ }^{\circ} \mathrm{C}$ and average annual rainfall ranging between 639-743 $\mathrm{mm}$ (Météofrance, 2016). The experimental designs of the two sites are presented in Fig. 1. Thirty-two plots of $12 \mathrm{~m}$ x $18 \mathrm{~m}$ each were planted with $1.5 \mathrm{~m}$ length unrooted cuttings of the two poplar clones, Skado (Populus trichocarpa $x$ P. maximowiczii section Tacahamaca) and I-214 (P. deltoides $x$ P. nigra section Aigeiros), at a spacing of 1.8 $\mathrm{m} \times 2.75 \mathrm{~m}$ with a plant density of 2,200 trees ha ${ }^{-1}$ (Ciadamidaro et al. (2017). These two clones were selected for their high biomass production and reduced PTE accumulation in their harvestable parts according to the Phytopop project (Pottier et al., 2015). Half of the trees were inoculated with a mixture of endomycorrhizal (Rhizophagus intraradices BEG140, Funelliformis mosseae BEG95, F. geosporum BEG199, Claroideoglomus claroideum BEG96, C. etunicatum BEG92, Glomus microaggregatum BEG56, Rhizophagus irregulare DAOM1971989) and ectomycorrhizal (Hebeloma mesophaeum, Amanita rubescens, Laccaria proxima, Paxillus involutus, Pisolithus arrhizus and Scleroderma citrinum) strains. The inoculum was spread at the foot of the cuttings, at the moment of plantation. Each tree received 26,000 propagules of ectomycorrhizal and endomycorrhizal fungi, the latest being dominant in the mixture following the manufacturers' recommendations (Ciadamidaro et al., 2017). One additional plot in each site was left unplanted and used as control (P33 and F33). 


\subsection{Sampling and analysis of soil and sediment}

At both sites, a sampling campaign was carried out during the establishment of the poplar plantation in 2011. We selected 8 plots per site corresponding to the least $\left(\mathrm{F}_{\mathrm{L}}, \mathrm{P}_{\mathrm{L}}\right)$ and the most $\left(\mathrm{F}_{\mathrm{H}}, \mathrm{P}_{\mathrm{H}}\right)$ metal polluted areas at each site (Fig. 1). In each plot, ten soil samples were collected with a hand auger at $20 \mathrm{~cm}$ from 10 planted poplars. In October 2012 (Fresnes) and September 2013 (Pierrelaye), 10 topsoil samples $(0-20 \mathrm{~cm})$ per plot were again collected at each site. Representative samples obtained by quartering following the French standard X31100 were oven-dried at $40^{\circ} \mathrm{C}$ until constant weight and ground with a grinder (agate mortar, Retsch RM100).

For both sites, physico-chemical analyses were performed by an external laboratory (Galys, Blois, France) on the 8 soil and sediment samples. They included: particle size distribution, available $\mathrm{P}\left(\mathrm{P}_{2} \mathrm{O}_{5}\right)$ (NF ISO 11263), exchangeable $\mathrm{Ca}(\mathrm{CaO}), \mathrm{Mg}(\mathrm{MgO}), \mathrm{K}$ $\left(\mathrm{K}_{2} \mathrm{O}\right)$ and $\mathrm{Na}\left(\mathrm{Na}_{2} \mathrm{O}\right)$, organic matter $(\mathrm{OM})$ (NF ISO 14235), total nitrogen (N) (NF ISO 13878), available $\mathrm{N}\left(\mathrm{NH}_{4}{ }^{+}\right.$and $\left.\mathrm{NO}_{3}{ }^{-}\right)$(ISO/TS 14256-1 / NF EN ISO 11732; NF EN ISO 13395), total $\mathrm{CaCO}_{3}$ (NF ISO 10693), cation exchange capacity (CEC) (NF X 31-130) and soluble bore (B) (NF X 31-122).

Total concentrations of major and trace elements of soil and sediment samples were determined in 2011. Before analysis, $0.5 \mathrm{~g}$ samples were sieved to $<200 \mu \mathrm{m}$ (Retsch AS 200 digit) then digested at $180^{\circ} \mathrm{C}$ for $20 \mathrm{~min}$ with $2 \mathrm{~mL}$ of nitric acid $(67 \%), 6 \mathrm{~mL}$ of hydrochloric acid (34\%) and $2 \mathrm{~mL}$ of hydrofluoric acid (48\%). Extracts were neutralized by $20 \mathrm{~mL}$ of boric acid (4\%) and filtered using $0.45 \mu \mathrm{m}$ Whatman ${ }^{\circledR}$ filter paper. Total concentrations of Al, As, $\mathrm{Ca}, \mathrm{Cd}, \mathrm{Co}, \mathrm{Cr}, \mathrm{Cu}, \mathrm{Fe}, \mathrm{K}, \mathrm{Mg}, \mathrm{Na}, \mathrm{Ni}, \mathrm{Pb}, \mathrm{Zn}$ were measured using ICP-OES (Ultima 2, Jobin Yvon Horiba). Soil samples which presented element concentrations below the limit of quantification (LQ), i.e. As and Cd (LQ As $<5 \mathrm{mg} \mathrm{kg}^{-1}$, LQ $\mathrm{Cd}<2 \mathrm{mg} \mathrm{kg}^{-1}$ ), were analyzed using ICP-MS (Agilent 7500). Two standard reference materials were included for analytical quality control (PACS-2, National Research Council of Canada; NCD 73310, Stream sediment). Recovery rates ranged between $92-110 \%$ for $\mathrm{Cd}, 87-101 \%$ for $\mathrm{Cu}, 83-92 \%$ for $\mathrm{Pb}$ and $87-105 \%$ for $\mathrm{Zn}$. For the other elements, recovery rates ranged from $72 \%$ to $112 \%$.

$\mathrm{Ca}\left(\mathrm{NO}_{3}\right)_{2}$-extractable fractions of PTE were determined in soil and sediment samples collected in 2011, 2012 and 2013. Extractions of $\mathrm{As}, \mathrm{Cd}, \mathrm{Cr}, \mathrm{Cu}, \mathrm{Ni}, \mathrm{Pb}$ and $\mathrm{Zn}$ were performed with a $0.01 \mathrm{M} \mathrm{Ca}\left(\mathrm{NO}_{3}\right)_{2}$ solution to estimate the plant-available fraction of PTE in the soil and sediment samples. Sixty grams of dried samples, sieved to $2 \mathrm{~mm}$, were shaken 
(Heidolph Reax 2) with $120 \mathrm{~mL}$ of $\mathrm{Ca}\left(\mathrm{NO}_{3}\right)_{2}(0.01 \mathrm{M})$ for 48 hours. The resulting soil and sediment mixtures were filtered on filtration units at $0.45 \mu \mathrm{m}$ (Millipore). Eluates were acidified to a $\mathrm{pH}<2$ for preservation and analyzed by ICP-MS (Agilent 7500).

Soil and sediment pH were measured following the NF ISO 10390 (2005) standard. Five grams of sieved sample were shaken (Heidolph Reax 2) with $25 \mathrm{~mL}$ of distilled water for $1 \mathrm{hr}$, then left to rest for $1 \mathrm{hr}$. The $\mathrm{pH}$ was measured under constant stirring.

\subsection{Sampling and analysis of poplar leaves}

Poplar leaves were collected in the 8 previously selected plots, in October 2012 (Fresnes site) and September 2013 (Pierrelaye site). On each studied plot, 10 samples of leaves were harvested at around $1.70 \mathrm{~m}$ height at the same time as the sediment or soil sampling. Leaves were carefully washed with tap and deionized water, then oven-dried at $40^{\circ} \mathrm{C}$ until constant weight. Dry leaves were ground and $0.5 \mathrm{~g}$ were digested at $180{ }^{\circ} \mathrm{C}$ for 20 $\min$ in $10 \mathrm{~mL}$ of nitric acid (67\%) and $3 \mathrm{~mL}$ of ultra-pure water using a microwave digester (Mars Xpress, CEM). The digested samples were filtered to $<0.45 \mu \mathrm{m}$ (Millipore) and acidified to a $\mathrm{pH}<2$ for preservation. The analyses of $\mathrm{Cd}, \mathrm{Cr}, \mathrm{Cu}, \mathrm{Pb}$ and $\mathrm{Zn}$ concentrations were performed by ICP-OES (Agilent 720ES) or ICP-MS (Agilent 7500). Two standard references of plant material (white cabbage "BCR-679", Community Bureau of Reference and tobacco leaves "CTA-VTL-2") were included for analytical quality control. Recovery rates ranged between $111-113 \%$ for $\mathrm{Cd}, 75-78 \%$ for $\mathrm{Cr}, 117-119 \%$ for $\mathrm{Cu}, 126 \%$ for $\mathrm{Pb}$ (in tobacco leaves), and $107-118 \%$ for $\mathrm{Zn}$.

\subsection{Statistical analyses}

Statistical analyses were performed using R software version 3.2.3 (R Core Team, 2015). All data distributions were checked for normality (Shapiro test). Concentrations of soil extractable and leaf PTEs were compared between plots planted with inoculated and noninoculated poplars, among each site and clone using Kruskal-Wallis tests $(p<0.05)$. Student's t-tests for a single sample were run to compare soil PTEs data between 2011 and 2012 or 2013. Paired samples t-tests were used to compare $\mathrm{pH}$ data between 2011 and 2012 or 2013, for the 8 selected plots in each site. A Principal Component Analysis (PCA) was performed to explore the distribution of foliar PTE concentrations using the R package "FactoMineR". For values below the LQ, values were divided by 2 for the PCA. Correlations between PTEs data in poplars and soils were calculated using Pearson correlations tests $(\mathrm{p}<0.01$; R package Hmisc). 


\section{Results and discussion}

\subsection{Initial soil characterization}

The soil properties of both sites are presented in Table 1. According to the French GEPPA triangle (1963), the soil from the Pierrelaye site had a sand texture whereas the dredged sediment from the Fresnes site was a silt loam. Higher levels of OM and clay were found in the Fresnes plots, resulting in a higher CEC and suggesting a strong buffering capacity (Baize, 2000). The average $\mathrm{pH}$ at both sites was alkaline $(7.7 \pm 0.1$ and $7.6 \pm 0.1$ for Pierrelaye and Fresnes, respectively). Available $\mathrm{NO}_{3}{ }^{-}$concentrations at the Fresnes site were almost 3-fold higher than those at the Pierrelaye site. Ammonium concentrations were much lower than $\mathrm{NO}_{3}{ }^{-}$concentrations but showed an opposite trend.

Concentrations of total major elements were contrasted between the two sites (Table 2). Total $\mathrm{Al}, \mathrm{Fe}$ and $\mathrm{K}$ concentrations at the Pierrelaye site were about 30 times higher than those at the Fresnes site whereas the latter contained 2 to 5 times more $\mathrm{Ca}, \mathrm{Mg}$ and $\mathrm{Na}$. Regarding total PTE concentrations (Table 2), the Pierrelaye site showed high concentrations of $\mathrm{Cd}, \mathrm{Cu}, \mathrm{Pb}$ and $\mathrm{Zn}$ in the investigated plots compared with local usual agricultural concentrations (Lamy et al., 2006). At the Fresnes site, high concentrations of $\mathrm{Cd}, \mathrm{Cu}, \mathrm{Pb}$ and Zn were mostly found in the $\mathrm{F}_{\mathrm{H}}$ area according to threshold values in dredged sediment (MEDD, 2006). The $\mathrm{F}_{\mathrm{H}}$ area appeared to be the most heavily $\mathrm{Cd}$ and $\mathrm{Zn}$ contaminated area, although a high variability was noticed for Cd concentrations (from 0.93 to $67.1 \mathrm{mg} \mathrm{kg}^{-1}$ DW). PTE concentrations in Pierrelaye plots ranged between those found at the $F_{L}$ and $F_{H}$ areas.

$\mathrm{Ca}\left(\mathrm{NO}_{3}\right)_{2}$-extractable $\mathrm{Cd}, \mathrm{Cr}, \mathrm{Cu}, \mathrm{Ni}$ and $\mathrm{Pb}$ concentrations in soil and sediment (Table 3) were extremely low as almost all values were below limits of quantification (LQ). Zn-extractable concentrations ranged from $<0.06$ (LQ) to $1.56 \mathrm{mg} \mathrm{kg}^{-1} \mathrm{DW}$ and from $<0.06$ to $0.77 \mathrm{mg} \mathrm{kg}^{-1} \mathrm{DW}$ in the Pierrelaye and the Fresnes sites, respectively. Thus, the maximal $\mathrm{Zn}$ extractable fractions represented $0.43 \%$ of the total $\mathrm{Zn}$ concentrations at Pierrelaye and 0.03 $\%$ at Fresnes, showing a much higher Zn mobility at Pierrelaye. Regarding As, the maximal extractable fraction at Pierrelaye was higher $(0.32 \%)$ than that of Fresnes $(0.25 \%)$. In agreement with CEC values, higher extractable concentrations in soil were expected at Pierrelaye (Rieuwerts et al., 1998).

\subsection{Evolution of $\mathrm{pH}$ and PTE mobility}


At Pierrelaye, a low but significant decrease of the average $\mathrm{pH}$ (from $7.7 \pm 0.1$ to $7.2 \pm$ 0.1) was observed in the 8 selected plots after 2 years (see Supplemental Fig.1 for details). Soil extractable concentrations of PTEs increased significantly in most plots of the Pierrelaye site (Table 3). The increased extractable fractions of PTEs observed in the poplar planted plots at Pierrelaye between 2011 and 2013 can be linked to the decrease of the soil pH, which may have affected speciation of PTEs in soil, rendering PTEs more soluble (Kabata-Pendias, 2010a). Soil acidification has often been reported after afforestation (Jug et al., 1999; Makeschin, 1994), and may result from losses of base cations such as Ca and/or release of root acidic exudates involved in uptake mechanisms (Kabata-Pendias, 2004). However, the decrease in soil $\mathrm{pH}$ cannot be solely attributed to the presence of trees, as similar decreases were observed in the unplanted plots (see Supplemental Fig.1), in which increases of $\mathrm{Cr}, \mathrm{Cu}$, $\mathrm{Ni}, \mathrm{Pb}$ and $\mathrm{Zn}$ extractable fractions were also noticed. However, since most of the concentrations were under the LQ for the 2011 sampling, these conclusions must be taken cautiously.

Conversely, the average $\mathrm{pH}$ at Fresnes increased significantly from $7.6 \pm 0.1$ to $8.1 \pm$ 0.1, between 2011 and 2012 (Supplemental Fig.1). At the same site, sediment extractable concentrations of As and $\mathrm{Zn}$ significantly increased in some plots of the most contaminated area $\left(\mathrm{F}_{\mathrm{H}}\right)$. The same trend occurred with extractable $\mathrm{Cu}$ (in all plots) and $\mathrm{Pb}$ (in $\mathrm{FH}_{\mathrm{H}}$ ). Overall, higher extractable concentrations of PTEs in soil were measured at Pierrelaye. At the Fresnes site, the limited increase of PTE-extractable concentrations between 2011 and 2012 may be explained by the alkalinization of the sediment. Here, the changes in $\mathrm{pH}$ value may be related to the microbial activity and / or higher $\mathrm{CaCO}_{3}$ and $\mathrm{Ca}$ concentrations (van Hullebusch et al., 2005). Nevertheless, a longer-term monitoring of these field sites is needed to assess the evolution of $\mathrm{pH}$ and PTE mobility on these phytomanaged sites.

\subsection{Accumulation of major and trace elements in poplar leaves}

A principal component analysis (PCA) was first performed to characterize the accumulation of PTEs in leaves of both poplar clones grown at the two sites (Fig. 2). The first principal component (Dim1) opposed 4 variables (Fig. 2a), foliar $\mathrm{Cu}$ concentrations being negatively correlated to $\mathrm{Cd}, \mathrm{Zn}$ and $\mathrm{Cr}$ foliar concentrations. These negative correlations revealed a well-known antagonistic relationship between $\mathrm{Cu}$ and $\mathrm{Zn}$ in leaves, when high levels of these micronutrients were reported (Läuchli and Bieleski, 1983). The second 
principal component (Dim2) clustered poplar Skado clones from the Pierrelaye site, which accumulated the highest amounts of $\mathrm{Pb}$ (Fig. 2). Our analysis (Fig. 2b) clearly discriminated the two poplar clones, with the Skado clone accumulating more $\mathrm{Cd}, \mathrm{Cr}, \mathrm{Pb}$, and $\mathrm{Zn}$ than the I214 clone (except for I-214 at the F4 and F9 plots). Control of leaf PTE translocation might therefore be determined by genetic traits, as demonstrated in one of our previous study (Pottier et al., 2015) or other previous studies on Salicaceous trees (Castiglione et al., 2009; Konlechner et al., 2013; Laureysens et al., 2004).

In more details, both Skado and I-214 clones from the two sites exhibited excessive foliar concentrations of $\mathrm{Cd}$ and $\mathrm{Zn}$ compared to those usually measured in poplars grown on uncontaminated sites (Fig. 3). Indeed, Vandecasteele et al. (2003) reported baseline foliar concentrations for 2-year-old poplar clones grown in a tree-nursery of 2.0-4.4 mg Cd kg-1 DW and 60-184 $\mathrm{mg} \mathrm{Zn} \mathrm{kg}^{-1} \mathrm{DW}$ whereas in our case, foliar Cd concentrations ranged from 1.10 to $18.9 \mathrm{mg} \mathrm{kg}^{-1} \mathrm{DW}$ and from 1.29 to $14.2 \mathrm{mg} \mathrm{kg}^{-1} \mathrm{DW}$ in I-214 and Skado, respectively. For $\mathrm{Zn}$, foliar concentrations ranged from 101 to $748 \mathrm{mg} \mathrm{kg}^{-1} \mathrm{DW}$ and from 192 to $928 \mathrm{mg} \mathrm{kg}^{-1}$ DW in I-214 and Skado, respectively. The highest Cd and Zn concentrations were measured in poplar leaves collected in the most heavily contaminated area $\mathrm{F}_{H}$ at Fresnes (Fig. 3). No statistical differences were found between leaf Cd concentrations of I-214 and Skado at the Fresnes site, whereas Skado accumulated more Cd than I-214 at the Pierrelaye site. Skado accumulated more $\mathrm{Zn}$ than I-214 in most plots of the two sites. Similar concentration ranges of $\mathrm{Cd}$ and $\mathrm{Zn}$ in poplar leaves measured at the end of growing seasons were reported in several studies performed at moderately contaminated sites (Laureysens et al., 2004; Madejón et al., 2012; Mertens et al., 2004; Pottier et al., 2015). In our study, foliar Cd concentrations were strongly correlated with foliar $\mathrm{Zn}$ concentrations in both clones and sites ( $\mathrm{r}$ ranged from 0.74 to $0.92, \mathrm{p}<0.01$ ) as reported in various studies on poplar (Lettens et al., 2011; Migeon et al., 2009; Pottier et al., 2015). Although Cd is not an essential element for plant nutrition, it may be transferred to plants with similar mechanisms to $\mathrm{Zn}$, as it is chemically and physically similar to $\mathrm{Zn}$ (Kabata-Pendias, 2010b). In this regard, Pottier et al. (2015) pointed out a contribution of the NRAMP1 (Natural Resistance Associated Macrophage Protein 1) transporter for $\mathrm{Cd}$ and $\mathrm{Zn}$ accumulation by poplars. High concentrations of PTE in leaves can be the result of their bioavailability in the soil, high transpiration rate, and common transport pathways in plant tissues (Robinson et al., 2000).

Foliar $\mathrm{Cu}$ concentrations in both clones ranged within physiological values (Lettens et al., 2011) and did not vary between the two sites (Fig. 3). In contrast to I-214, foliar Pb 
concentrations in Skado were close or above baseline values at both sites $\left(1.5 \mathrm{mg} \mathrm{Pb} \mathrm{kg}{ }^{-1}\right.$ DW; Kalra, 1998). The highest concentrations of $\mathrm{Cr}$ in leaves were measured in I-214 and Skado clones at the Fresnes, these concentrations however remaining close to baseline values (about $2 \mathrm{mg} \mathrm{Cr} \mathrm{kg}^{-1} \mathrm{DW}$; Giachetti and Sebastiani, 2006).

Adequate nutrient concentrations in tree growth are crucial when considering biomass production and foliar diagnosis can be a useful tool to determine nutritional status. Among the nutrients measured in poplar leaves at the Pierrelaye site, $\mathrm{P}, \mathrm{Ca}, \mathrm{Mg}$ and $\mathrm{Mn}$ concentrations (Fig. 4) fell within the range of "optimal" levels found in I-214 leaves (Garbaye et al., 1980) and other poplar leaves (Kalra, 1998). Conversely, leaf K and Fe concentrations were lower than expected, suggesting a potential deficiency. Skado clones were characterized by higher $\mathrm{Ca}$ and Fe leaf concentrations, whereas I-214 contained more $\mathrm{Mg}(\mathrm{p}<0.05)$.

\subsection{Effects of mycorrhizal inoculation}

We evidenced a significant decrease in foliar $\mathrm{Zn}, \mathrm{Cu}, \mathrm{Pb}$ and $\mathrm{Cr}$ concentrations in inoculated Skado poplars compared with the non-inoculated ones at the Fresnes FH area (Fig. 3). In the same area, there was a clear similar tendency for $\mathrm{Zn}$ concentrations measured in the I-214 leaves, and Cd concentrations in the I-214 and Skado leaves, although not statistically significant. Noticeably, the impact of inoculation was only evidenced for Skado clones at the Fresnes $\mathrm{F}_{\mathrm{H}}$ area, which was characterized by the highest total PTE concentrations in soil (Table 2). This trend was confirmed by the PCA performed with PTE concentrations in leaves, which discriminated non-inoculated Skado (F-ni-F5) and I-214 (F-ni-F4) with higher concentrations of $\mathrm{Zn}$ and $\mathrm{Cd}$ in leaves, as compared with inoculated Skado (F-i-F12) and I214 (F-i-F9), all from the Fresnes FH area (Fig. 2b). Conversely, inoculation also induced an increase of foliar $\mathrm{Cu}$ and $\mathrm{Zn}$ concentrations in some plots of $\mathrm{F}_{\mathrm{L}}$ and $\mathrm{P}_{\mathrm{L}}$ areas.

It is interesting to note that the filter function of arbuscular mycorrhizal fungi (AMF), in the case of highly contaminated soils, dominates the literature, as for example in the works described by Meier et al. (2012b) and Garg and Aggarwal (2012), most of the studies being performed in pot experiments. Conversely, some authors demonstrated that the inoculation of plants by AMF such as Glomus species significantly enhanced PTE translocation to the aboveground parts of plants (Meier et al., 2012a). Levels of PTEs in soil may also affect the role of arbuscular mycorrhizal symbiosis (Audet and Charest, 2007), which can lead to an increase of plant metal uptake at low soil PTE concentrations as well as a reduction of PTE bioavailability via fungal metal-binding processes at high soil PTE levels. The mechanisms 
underlying metal accumulation may involve metallothioneins, small proteins that bind metals in plant detoxification process, as demonstrated in a greenhouse experiment (Cicatelli et al., 2014). Garg and Aggarwal (2011) also reported that AMF induced the production of chelating agents (phytochelatins) and antioxidants (glutathione) to reduce PTE toxicity and translocation in plant shoots. By forming extraradical mycelium networks, AMF can also minimize the exposure of plants to excessive PTE levels by producing glomalins, proteins allowing PTE immobilization in hyphae (Cabral et al., 2015). The authors however often questioned the fact that investigations in field experiments are needed to demonstrate the applicability of their findings. Our work therefore corroborates this major conclusion. Compared with non-inoculated poplars, inoculation did not improve nutrient concentrations when considering $\mathrm{P}, \mathrm{K}, \mathrm{Ca}, \mathrm{Mg}, \mathrm{Fe}$ and $\mathrm{Mn}$ in leaves analyzed at the end of the growing season in 2013 (Fig. 4). Despite this, we measured significant increases in biomass production at both sites for the poplar Skado clone in early spring 2013 (Ciadamidaro et al., 2017). We might therefore conclude that mycorrhizal fungi may have increased the volume of soil explored by single trees, thus allowing for an improved production of biomass.

An increase in extractable PTE concentrations was significant in some plots (Table 3) planted with inoculated clones (on P31, P12, P23, F30, F31 and F9), suggesting an induction of PTE mobilization in soils by the inoculation. Mycorrhizal fungi can trigger root exudation of organic acids, and solubilize PTEs (Churchland and Grayston, 2014). Conversely, it is likely that the inoculation also decreased PTE mobility in other plots (P11, P23, F9 and F12), via metal-binding processes (Cicatelli et al., 2014). Moreover, the extractable PTE concentrations in soils was not correlated with the effect of inoculation on PTE accumulation by poplars (Fig. 2). As discussed in our previous paper (Ciadamidaro et al., 2017), mycorrhizal colonization rates did not differ statistically between the four areas $\left(\mathrm{F}_{\mathrm{L}}, \mathrm{F}_{\mathrm{H}}, \mathrm{P}_{\mathrm{L}}\right.$ and $\mathrm{P}_{\mathrm{H}}$ ), and therefore cannot explain the lowest accumulations of PTE in leaves of inoculated poplars, as compared with non-inoculated ones. As there are no means (and thereof no attempt) to definitely identify the mycorrhizal isolates that were added as biological amendments to the trees at the plantation, we could only speculate that the mycorrhizal fungi present in the inoculum would be more efficient than the endogenous mycorrhizal fungi in their filtering PTE capacity (by producing more glomalins for example).

\subsection{Influence of site conditions on PTE accumulation in poplar leaves}

Pearson correlation tests revealed a positive linear relationship between foliar $\mathrm{Zn}$ concentrations in both clones and extractable $\mathrm{Zn}$ concentrations in soil at the Fresnes site (rZn 
$=0.57$ for I-214, $\mathrm{rzn}=0.68$ for Skado; $\mathrm{p}<0.01)$. At the Pierrelaye site, $\mathrm{Cd}$ and $\mathrm{Zn}$ concentrations in Skado leaves were positively correlated with extractable concentrations in soil $\left(\mathrm{rCd}_{\mathrm{Cd}}=0.50, \mathrm{rZn}=0.53 ; \mathrm{p}<0.01\right)$, as previously reported (Madejón et al., 2004; Pourrut et al., 2011). Despite similar concentrations of extractable PTEs between some plots of the two sites, poplars could accumulate more PTEs in their leaves at the Fresnes site, which implies other soil parameters in soil-plant transfers of PTEs. The addition of soil parameters in the PCA as illustrative variables highlighted potential correlations between leaf $\mathrm{Cd}$ and $\mathrm{Zn}$ concentrations and their total concentrations in soil, $\mathrm{CaCO}_{3}, \mathrm{~N}, \mathrm{OM}$, silt, $\mathrm{P}_{2} \mathrm{O}_{2}, \mathrm{CEC}, \mathrm{CaO}$, $\mathrm{K}_{2} \mathrm{O}, \mathrm{NO}_{3}{ }^{-}$and clay (Supplemental Table 1). This analysis suggested that PTEs were more bioavailable in more fertile soils, which is indeed the case for the Fresnes soil. Besides, negative correlations were found between $\mathrm{K}$ in leaves and soil extractable concentrations of As, $\mathrm{Cu}$, Ni (for I-214) and Cd (for Skado). As foliar K concentrations were below optimal values (Fig. 4), those negative correlations suggested an inhibition of $\mathrm{K}$ accumulation in leaf tissues by these PTEs.

Bioconcentration factors (BCFs) were calculated as the ratio of the PTE concentrations in leaves $\left(\mathrm{mg} \mathrm{kg}^{-1} \mathrm{DW}\right)$ and the total PTE concentration in soil $\left(\mathrm{mg} \mathrm{kg}^{-1} \mathrm{DW}\right)$. $\mathrm{A} B C F$ value above 1 indicates that the plant is a metal accumulator. $\mathrm{Cd}$ and $\mathrm{Zn} \mathrm{BCFs}$ were highest in $\mathrm{F}_{\mathrm{L}}$ and $\mathrm{P}_{\mathrm{L}}$ (the least contaminated areas of Fresnes and Pierrelaye sites, respectively), where almost all values were above 1 for both clones (Table 4). At both sites, $\mathrm{Cd}$ BCF values were higher than $\mathrm{Zn}$ BCF values and Skado clones accumulated more Cd and $\mathrm{Zn}$ in their leaves than I-214. Conversely, poplars did not accumulate $\mathrm{Zn}$ in $\mathrm{F}_{\mathrm{H}}(\mathrm{BCF}<1)$, the most contaminated area of the Fresnes site. Such Cd and Zn BCF values were reported in other poplar species in field trials, which confirmed their abilities to take up and transfer these two PTEs in their leaves (Migeon et al., 2009; Vandecasteele et al., 2003). At the Fresnes site, BCF values calculated for inoculated poplars were higher than those of non-inoculated poplars in most cases, suggesting that mycorrhizal fungi did not act as an effective barrier against poplar PTE translocation in leaves, considering soil total element concentrations in soil. Besides, poplars did not accumulate $\mathrm{Cr}, \mathrm{Cu}$ and $\mathrm{Pb}$ in their leaves (BCFs $<1$ ).

\subsection{Lessons from the field and recommendations}

In recent years, poplar SRC on uncontaminated soils have been widely studied under field conditions in Europe to promote their environmental (Tricker et al., 2009; Verlinden et al., 2013) and socio-economic advantages (Marron et al., 2012). On contaminated lands, the application of aided phytostabilization with bioenergy crops at field scale is a great challenge 
that aims at controlling and reducing the environmental impact of those sites while developing economic opportunities. With regard to this purpose, feedback from field study is scarce.

Many authors highlighted the necessity to select appropriate combinations of plant genotypes and mycorrhizal strains for phytoremediation purposes (Lingua et al., 2008; Mrnka et al., 2012). In fact, specific root exudates released by trees trigger the expression of mycorrhization genes, resulting in symbiotic relationships between plants and mycorrhizal fungi (Churchland and Grayston, 2014). Depending on their type (endo- or ectomycorrhizas), mycorrhizal fungi may interact differently with plants, by transferring limited or larger amount of nutrients or PTEs to their hosts. The role of mycorrhizal fungi in poplar growth, tolerance, and metal accumulation in tissues has been largely demonstrated in pot experiments under controlled conditions, in uncontaminated or metal contaminated soils (Baum et al., 2002; Cicatelli et al., 2014; Mrnka et al., 2012) but rarely in field conditions. On a slightly contaminated site, Bissonnette et al. (2010) reported that arbuscular mycorrhizal fungi inoculation had no significant effect on $\mathrm{Cd}$ accumulation in poplars shoots used for phytoextraction,. In most of the less contaminated areas of our study, PTE concentrations of poplar leaves did not vary under inoculation. Interestingly, our results showed a significant decrease in foliar concentrations of $\mathrm{Zn}, \mathrm{Cu}, \mathrm{Pb}$ and $\mathrm{Cr}$ for the poplar Skado clone grown on the most highly polluted areas, which confirms fungal mycorrhizal symbiosis dynamics at elevated soil PTE concentrations (Audet and Charest, 2007; Bojarczuk and KieliszewskaRokicka, 2010). Therefore, the inocula and poplar cultivars used in this study were strongly influenced by the sites conditions (levels of PTEs in soil, OM, CEC, and certainly native microbial communities, vegetation, etc.). With the aim of managing risk at contaminated sites, further studies are needed to isolate fungal strains able to reduce $\mathrm{Cd}$ and $\mathrm{Zn}$ transfers in the aboveground parts of poplars, to reach baseline concentrations in tissues. Tripartite relationship including bacteria and fungi should also be considered to optimize root colonization by mycorrhizal fungi and reduce PTE transfers in poplars (Labbé et al., 2014).

Despite the positive effect of the inoculation observed in Skado clones in situ, the high $\mathrm{Cd}$ and $\mathrm{Zn}$ concentrations measured in poplar leaves is of concern since PTEs may disseminate in the environment after leaf abscission. Litter decomposition rates may be strongly reduced by the metal pollution, affecting consequently soil physicochemical and biological conditions (Berg et al., 1991). Therefore, a risk assessment is required to characterize $\mathrm{Cd}$ and $\mathrm{Zn}$ accumulation in the litter layer, as well as their potential transfers to other organisms since changes in metal speciation can be expected (Nirola et al., 2016). Based 
on the outcomes, PTEs could be removed from contaminated sites by collecting the leaves after abscission. Also, the use of poplars for energy production in phytomanagement strategies requires low concentrations of PTEs in wood, in agreement with current local regulations. As poplars accumulate lower amounts of PTEs in wood than in leaves, we assume that $\mathrm{Cd}$ concentrations in wood are 1.2 to 2 -fold lower than in leaves, and $\mathrm{Zn}$ concentrations, 4 to 10 -fold lower considering similar foliar concentrations and moderately contaminated soils (Laureysens et al., 2004; Madejón et al., 2004; Migeon et al., 2009). In comparison with reference values obtained from a non-contaminated area (Chalot et al., 2012), Cd and Zn estimated concentrations in the wood of the present poplars may be in excess by the end of the first rotation. Valorization options (torrefaction, pyrolysis) of noninoculated 7-year-old Skado poplars were investigated at a $\mathrm{Zn}$ and $\mathrm{Cd}$ contaminated site in Northern France (Bert et al., 2017). The Leforest site showed close physico-chemical characteristics, especially the soil texture and low $\mathrm{CaCl}_{2}$-extractrable fractions, compared to the Fresnes site (Foulon et al., 2016). Wood concentrations of $\mathrm{Cd}$ and $\mathrm{Zn}$ after the first harvest were $5.66 \pm 0.51 \mathrm{mg} \mathrm{Cd} \mathrm{kg}^{-1} \mathrm{DW}$ and $64.10 \pm 11.61 \mathrm{mg} \mathrm{Zn} \mathrm{kg}^{-1} \mathrm{DW}$, suggesting that $\mathrm{Cd}$ could be of concern for Skado poplar conversion processes as the concentration of $\mathrm{Cd}$ exceeded its baseline value $(0.53 \pm 0.1 \mathrm{mg} \mathrm{Cd} \mathrm{kg-1} \mathrm{DW;} \mathrm{Bert} \mathrm{et} \mathrm{al.} \mathrm{(2017)).} \mathrm{In} \mathrm{addition,} \mathrm{in}$ France, a threshold value for $\mathrm{Cd}$ was stated at $5 \mathrm{mg} \mathrm{kg}^{-1} \mathrm{DW}$ to regulate the use of wood as fuel in combustion plants (MEDDE, 2013). In some plants covered by this regulation, Cd concentration in Skado poplar could limit its use for combustion. Concerning the use of Cdenriched poplar wood as feedstock for pyrolysis and torrefaction, the potential limitation due to $\mathrm{Cd}$ could be overcome if end-products can be treated or upgraded. Due to the short duration of the study (3 years), we were not able to harvest poplars and report the Cd concentration of the woody biomass, poplar SRC being usually harvested on a cycle of 6 to 8 years (Marron et al., 2012). Nevertheless, we expect that the upcoming results would be comparable to those obtained in Bert et al. (2017). One can expect that inoculated poplars with efficient mycorrhiza for $\mathrm{Cd}$ sequestration could contribute to decrease the $\mathrm{Cd}$ wood accumulation in poplars. These hypotheses need to be assessed in further long-term field studies.

\section{Conclusion}

The implementation of large field trials is a key stage to provide theoretical and technical knowledge in phytotechnologies. Our large-scale study pointed out the complexity of environmental processes that are not taken into account in greenhouse experiments. With 
the objective of limiting poplar metal accumulation in the aboveground parts of poplars and optimizing their growth in situ, mycorrhizal fungi inoculation revealed to be effective in reducing $\mathrm{Zn}, \mathrm{Cu}, \mathrm{Pb}$ and $\mathrm{Cr}$ accumulation in Skado leaves after two growing seasons, in highly polluted areas. The same trend was also observed for most plots planted with I-214 or Skado clones. Therefore, mycorrhizal fungi interacted differently with poplars depending on the cultivars, soil physico-chemical properties and certainly other conditions specific to each site (vegetation, native microbial communities, etc.). In terms of territorial and sustainable development, the use of mycorrhizal poplars tends to be efficient in heavily polluted areas but further research is needed to identify and isolate fungal strains that have the capacity to reduce $\mathrm{Cd}$ and $\mathrm{Zn}$ accumulation in poplar tissues, to reach baseline concentrations for risk management and valorization purposes. Otherwise, poplar wood and leaves have both to be safely managed to prevent food chain contamination and pollutant emissions. Despite these promising results, a better understanding of interactions between mycorrhizal fungi, poplars and soil conditions in the field are still needed to allow operational implementations of phytomanagement options.

\section{Acknowledgments}

This work was financially supported by national fundings through BIOFILTREE (ANR Programme Blanc International, 2010-INTB-1703-03) and Phytosed 2 (ADEME, 1072 C0044 and VNF, 2011/01/02). P. Phanthavongsa was granted through the Demophyto project (ADEME, $1472 \mathrm{C} 0059$ and VNF, N²014 /I01/21). The authors thanked Francis Guillot and Fabrice Richez for their technical help during the sampling campaigns. 


\section{References}

Audet, P., Charest, C. (2007) Dynamics of arbuscular mycorrhizal symbiosis in heavy metal phytoremediation: Meta-analytical and conceptual perspectives. Environmental Pollution 147, 609-614.

Baize, D. (2000) Guide des analyses en pédologie: 2e édition, revue et augmentée. Editions Quae.

Baum, C., Stetter, U., Makeschin, F. (2002) Growth response of Populus trichocarpa to inoculation by the ectomycorrhizal fungus Laccaria laccata in a pot and a field experiment. Forest Ecology and Management 163, 1-8.

Bell, T.H., Cloutier-Hurteau, B., Al-Otaibi, F., Turmel, M.-C., Yergeau, E., Courchesne, F., St-Arnaud, M. (2015) Early rhizosphere microbiome composition is related to the growth and Zn uptake of willows introduced to a former landfill. Environmental Microbiology 17, 30253038 .

Berg, B., Ekbohm, G., Söderström, B., Staaf, H. (1991) Reduction of decomposition rates of scots pine needle litter due to heavy-metal pollution. Water, Air, and Soil Pollution 59, 165 177.

Bert, V., Allemon, J., Sajet, P., Dieu, S., Papin, A., Collet, S., Gaucher, R., Chalot, M., Michiels, B., Raventos, C. (2017) Torrefaction and pyrolysis of metal-enriched poplars from phytotechnologies: Effect of temperature and biomass chlorine content on metal distribution in end-products and valorization options. Biomass and Bioenergy 96, 1-11.

Bissonnette, L., St-Arnaud, M., Labrecque, M. (2010) Phytoextraction of heavy metals by two Salicaceae clones in symbiosis with arbuscular mycorrhizal fungi during the second year of a field trial. Plant and Soil 332, 55-67.

Bojarczuk, K., Kieliszewska-Rokicka, B. (2010) Effect of Ectomycorrhiza on $\mathrm{Cu}$ and $\mathrm{Pb}$ Accumulation in Leaves and Roots of Silver Birch (Betula pendula Roth.) Seedlings Grown in Metal-Contaminated Soil. Water, Air, and Soil Pollution 207, 227-240.

Cabral, L., Soares, C.R.F.S., Giachini, A.J., Siqueira, J.O. (2015) Arbuscular mycorrhizal fungi in phytoremediation of contaminated areas by trace elements: mechanisms and major benefits of their applications. World Journal of Microbiology and Biotechnology 31, 16551664.

Castiglione, S., Todeschini, V., Franchin, C., Torrigiani, P., Gastaldi, D., Cicatelli, A., Rinaudo, C., Berta, G., Biondi, S., Lingua, G. (2009) Clonal differences in survival capacity, copper and zinc accumulation, and correlation with leaf polyamine levels in poplar: A largescale field trial on heavily polluted soil. Environmental Pollution 157, 2108-2117.

Chalot, M., Blaudez, D., Rogaume, Y., Provent, A.-S., Pascual, C. (2012) Fate of Trace Elements during the Combustion of Phytoremediation Wood. Environmental Science \& Technology 46, 13361-13369.

Churchland, C., Grayston, S.J. (2014) Specificity of plant-microbe interactions in the tree mycorrhizosphere biome and consequences for soil $\mathrm{C}$ cycling. Frontiers in Microbiology 5.

Ciadamidaro, L., Girardclos, O., Bert, V., Zappelini, C., Yung, L., Foulon, J., Papin, A., Roy, S., Blaudez, D., Chalot, M. (2017) Poplar biomass production at phytomanagement sites is significantly enhanced by mycorrhizal inoculation. Environmental and Experimental Botany $139,48-56$. 
Cicatelli, A., Lingua, G., Todeschini, V., Biondi, S., Torrigiani, P., Castiglione, S. (2010) Arbuscular mycorrhizal fungi restore normal growth in a white poplar clone grown on heavy metal-contaminated soil, and this is associated with upregulation of foliar metallothionein and polyamine biosynthetic gene expression. Annals of Botany 106, 791-802.

Cicatelli, A., Torrigiani, P., Todeschini, V., Biondi, S., Castiglione, S., Lingua, G. (2014) Arbuscular mycorrhizal fungi as a tool to ameliorate the phytoremediation potential of poplar: biochemical and molecular aspects. iForest - Biogeosciences and Forestry 7, 333-341.

Colpaert, J.V., Wevers, J.H.L., Krznaric, E., Adriaensen, K. (2011) How metal-tolerant ecotypes of ectomycorrhizal fungi protect plants from heavy metal pollution. Annals of Forest Science 68, 17-24.

Cundy, A.B., Bardos, R.P., Church, A., Puschenreiter, M., Friesl-Hanl, W., Müller, I., Neu, S., Mench, M., Witters, N., Vangronsveld, J. (2013) Developing principles of sustainability and stakeholder engagement for "gentle" remediation approaches: The European context. Journal of Environmental Management 129, 283-291.

Delplanque, M., Collet, S., Del Gratta, F., Schnuriger, B., Gaucher, R., Robinson, B., Bert, V. (2013) Combustion of Salix used for phytoextraction: The fate of metals and viability of the processes. Biomass and Bioenergy 49, 160-170.

Evangelou, M.W., Deram, A. (2014) Phytomanagement: a realistic approach to soil remediating phytotechnologies with new challenges for plant science. Int J Plant Biol Res 2, 1023.

Foulon, J., Zappelini, C., Durand, A., Valot, B., Girardclos, O., Blaudez, D., Chalot, M. (2016) Environmental metabarcoding reveals contrasting microbial communities at two poplar phytomanagement sites. Science of The Total Environment 571, 1230-1240.

Garbaye, J., Courrier, G., Masar, L., (1980) Nutrition minérale et production des peupliers «Robusta» et «I-214» en populiculture traditionnelle dans le nord du bassin parisien, Annales des Sciences Forestières. EDP Sciences, pp. 159-172.

Garg, N., Aggarwal, N. (2012) Effect of mycorrhizal inoculations on heavy metal uptake and stress alleviation of Cajanus cajan (L.) Millsp. genotypes grown in cadmium and lead contaminated soils. Plant Growth Regulation 66, 9-26.

Giachetti, G., Sebastiani, L. (2006) Development and chromium uptake in hybrid poplars cultivated on substrate polluted with industrial slags. Advances in Horticultural Science 20, 193-198.

Järup, L. (2003) Hazards of heavy metal contamination. British Medical Bulletin 68, 167-182.

Jug, A., Makeschin, F., Rehfuess, K.E., Hofmann-Schielle, C. (1999) Short-rotation plantations of balsam poplars, aspen and willows on former arable land in the Federal Republic of Germany. III. Soil ecological effects. Forest Ecology and Management 121, 8599.

Kabata-Pendias, A. (2004) Soil-plant transfer of trace elements-an environmental issue. Geoderma 122, 143-149.

Kabata-Pendias, A. (2010a) Soils and Soil Processes, Trace Elements in Soils and Plants, Fourth Edition. CRC Press, pp. 37-63.

Kabata-Pendias, A. (2010b) Trace Elements of Group 12 (Previously of Group IIb), Trace Elements in Soils and Plants, Fourth Edition. CRC Press, pp. 275-314. 
Kalra, Y. (1998) Handbook of reference methods for plant analysis. CRC Press.

Konlechner, C., Türktaş, M., Langer, I., Vaculík, M., Wenzel, W.W., Puschenreiter, M., Hauser, M.-T. (2013) Expression of zinc and cadmium responsive genes in leaves of willow (Salix caprea L.) genotypes with different accumulation characteristics. Environmental Pollution 178, 121-127.

Labbé, J.L., Weston, D.J., Dunkirk, N., Pelletier, D.A., Tuskan, G.A. (2014) Newly identified helper bacteria stimulate ectomycorrhizal formation in Populus. Frontiers in Plant Science 5, 579 .

Lamy, I., Van Oort, F., Dère, C., Baize, D. (2006) Use of major- and trace-element correlations to assess metal migration in sandy Luvisols irrigated with wastewater. European Journal of Soil Science 57, 731-740.

Läuchli, A., Bieleski, R.L. (1983) Inorganic plant nutrition. Springer-Verlag.

Laureysens, I., Blust, R., De Temmerman, L., Lemmens, C., Ceulemans, R. (2004) Clonal variation in heavy metal accumulation and biomass production in a poplar coppice culture: I. Seasonal variation in leaf, wood and bark concentrations. Environmental Pollution 131, 485494.

Laureysens, I., De Temmerman, L., Hastir, T., Van Gysel, M., Ceulemans, R. (2005) Clonal variation in heavy metal accumulation and biomass production in a poplar coppice culture. II. Vertical distribution and phytoextraction potential. Environmental Pollution 133, 541-551.

Lettens, S., Vandecasteele, B., De Vos, B., Vansteenkiste, D., Verschelde, P. (2011) Intraand inter-annual variation of $\mathrm{Cd}, \mathrm{Zn}, \mathrm{Mn}$ and $\mathrm{Cu}$ in foliage of poplars on contaminated soil. Science of The Total Environment 409, 2306-2316.

Lingua, G., Franchin, C., Todeschini, V., Castiglione, S., Biondi, S., Burlando, B., Parravicini, V., Torrigiani, P., Berta, G. (2008) Arbuscular mycorrhizal fungi differentially affect the response to high zinc concentrations of two registered poplar clones. Environmental Pollution 153, 137-147.

Madejón, P., Ciadamidaro, L., Marañón, T., Murillo, J.M. (2012) Long-Term Biomonitoring of Soil Contamination Using Poplar Trees: Accumulation of Trace Elements in Leaves and Fruits. International Journal of Phytoremediation 15, 602-614.

Madejón, P., Marañón, T., Murillo, J.M., Robinson, B. (2004) White poplar (Populus alba) as a biomonitor of trace elements in contaminated riparian forests. Environmental Pollution 132, 145-155.

Makeschin, F. (1994) Effects of energy forestry on soils. Biomass and Bioenergy 6, 63-79.

Marron, N., Beimgraben, T., Bes de Berc, L. (2012) Cost reduction and efficiency improvement of short rotation coppice. CCREF Final Report, Champenoux.

MEDD (2006) Arrêté du 9 août 2006 relatif aux niveaux à prendre en compte lors d'une analyse de rejets dans les eaux de surface ou de sédiments marins, estuariens ou extraits de cours d'eau ou canaux relevant respectivement des rubriques 2.2.3.0, 4.1.3.0 et 3.2.1.0 de la nomenclature annexée à l'article R. 214-1 du code de l'environnement. Texte ${ }^{\circ} 15$. Journal Officiel de la République Française.

MEDDE (2013) Arrêté du 24 septembre 2013 relatif aux prescriptions générales applicables aux installations relevant du régime de l'enregistrement au titre de la rubrique $\mathrm{n}^{\circ} 2910$-B de la nomenclature des installations classées pour la protection de l'environnement. Texte $\mathrm{n}^{\circ} 10$. Journal Officiel de la République Française. 
Meier, S., Borie, F., Bolan, N., Cornejo, P. (2012a) Phytoremediation of Metal-Polluted Soils by Arbuscular Mycorrhizal Fungi. Critical Reviews in Environmental Science and Technology 42, 741-775.

Meier, S., Borie, F., Curaqueo, G., Bolan, N., Cornejo, P. (2012b) Effects of arbuscular mycorrhizal inoculation on metallophyte and agricultural plants growing at increasing copper levels. Applied Soil Ecology 61, 280-287.

Mench, M., Lepp, N., Bert, V., Schwitzguébel, J.-P., Gawronski, S.W., Schröder, P., Vangronsveld, J. (2010) Successes and limitations of phytotechnologies at field scale: outcomes, assessment and outlook from COST Action 859. Journal of Soils and Sediments $10,1039-1070$.

Mertens, J., Vervaeke, P., Schrijver, A.D., Luyssaert, S. (2004) Metal uptake by young trees from dredged brackish sediment: limitations and possibilities for phytoextraction and phytostabilisation. Science of The Total Environment 326, 209-215.

Météofrance (2016) Données climatiques. http://www.meteofrance.com/climat/france. Accessed 2016.01.

Migeon, A., Richaud, P., Guinet, F., Chalot, M., Blaudez, D. (2009) Metal Accumulation by Woody Species on Contaminated Sites in the North of France. Water, Air, and Soil Pollution 204, 89.

Mrnka, L., Kuchár, M., Cieslarová, Z., Matějka, P., Száková, J., Tlustoš, P., Vosátka, M. (2012) Effects of Endo- and Ectomycorrhizal Fungi on Physiological Parameters and Heavy Metals Accumulation of Two Species from the Family Salicaceae. Water, Air, \& Soil Pollution 223, 399-410.

Nirola, R., Megharaj, M., Venkateswarlu, K., Aryal, R., Correll, R., Naidu, R. (2016) Assessment of metal toxicity and bioavailability in metallophyte leaf litters and metalliferous soils using Eisenia fetida in a microcosm study. Ecotoxicology and Environmental Safety $129,264-272$.

Pottier, M., García de la Torre, V.S., Victor, C., David, L.C., Chalot, M., Thomine, S. (2015) Genotypic variations in the dynamics of metal concentrations in poplar leaves: A field study with a perspective on phytoremediation. Environmental Pollution 199, 73-82.

Pourrut, B., Lopareva-Pohu, A., Pruvot, C., Garçon, G., Verdin, A., Waterlot, C., Bidar, G., Shirali, P., Douay, F. (2011) Assessment of fly ash-aided phytostabilisation of highly contaminated soils after an 8-year field trial: Part 2. Influence on plants. Science of The Total Environment 409, 4504-4510.

Pulford, I.D., Watson, C. (2003) Phytoremediation of heavy metal-contaminated land by trees-a review. Environment International 29, 529-540.

R Core Team (2015). R: A language and environment for statistical computing. R Foundation for Statistical Computing, Vienna, Austria. https://www.R-project.org.

Rieuwerts, J., Thornton, I., Farago, M., Ashmore, M. (1998) Factors influencing metal bioavailability in soils: preliminary investigations for the development of a critical loads approach for metals. Chemical Speciation \& Bioavailability 10, 61-75.

Robinson, B., Mills, T., Petit, D., Fung, L., Green, S., Clothier, B. (2000) Natural and induced cadmium-accumulation in poplar and willow: Implications for phytoremediation. Plant and Soil 227, 301-306. 
Salt, D.E., Blaylock, M., Kumar, N.P.B.A., Dushenkov, V., Ensley, B.D., Chet, I., Raskin, I. (1995) Phytoremediation: A Novel Strategy for the Removal of Toxic Metals from the Environment Using Plants. Nat Biotech 13, 468-474.

Sell, J., Kayser, A., Schulin, R., Brunner, I. (2005) Contribution of Ectomycorrhizal Fungi to Cadmium Uptake of Poplars and Willows from a Heavily Polluted Soil. Plant and Soil 277, 245-253.

Tricker, P.J., Pecchiari, M., Bunn, S.M., Vaccari, F.P., Peressotti, A., Miglietta, F., Taylor, G. (2009) Water use of a bioenergy plantation increases in a future high CO2 world. Biomass and Bioenergy 33, 200-208.

van Hullebusch, E.D., Lens, P.N.L., Tabak, H.H. (2005) Developments in Bioremediation of Soils and Sediments Polluted with Metals and Radionuclides. 3. Influence of Chemical Speciation and Bioavailability on Contaminants Immobilization/Mobilization Bio-processes. Reviews in Environmental Science and Bio/Technology 4, 185-212.

Vandecasteele, B., Lauriks, R., De Vos, B., Tack, F.M. (2003) Cd and Zn concentration in hybrid poplar foliage and leaf beetles grown on polluted sediment-derived soils. Environ Monit Assess 89, 263-283.

Vangronsveld, J., Herzig, R., Weyens, N., Boulet, J., Adriaensen, K., Ruttens, A., Thewys, T., Vassilev, A., Meers, E., Nehnevajova, E., van der Lelie, D., Mench, M. (2009)

Phytoremediation of contaminated soils and groundwater: lessons from the field. Environmental Science and Pollution Research 16, 765-794.

Verlinden, M.S., Broeckx, L.S., Van den Bulcke, J., Van Acker, J., Ceulemans, R. (2013) Comparative study of biomass determinants of 12 poplar (Populus) genotypes in a highdensity short-rotation culture. Forest Ecology and Management 307, 101-111. 

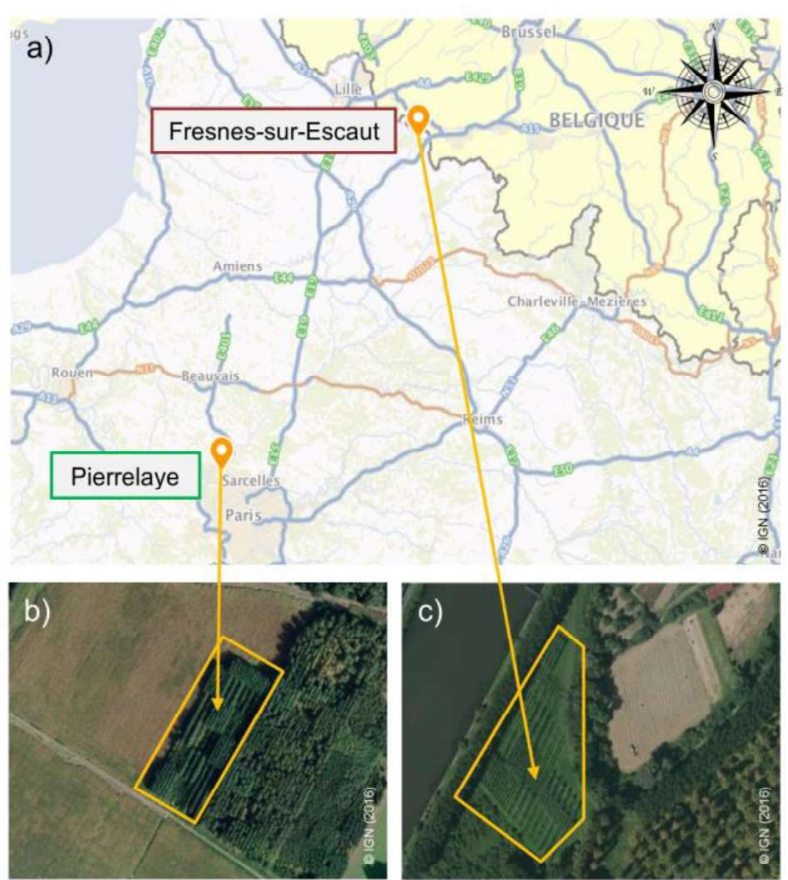

\begin{tabular}{|c|c|c|}
\hline \multicolumn{3}{|c|}{$P_{L}$} \\
\hline P33 & P22 & P11 \\
\hline P32 & P21 & P10 \\
\hline P31 & P20 & P9 \\
\hline P30 & P19 & P8 \\
\hline P29 & P18 & P7 \\
\hline P28 & P17 & P6 \\
\hline P27 & P16 & P5 \\
\hline P26 & P15 & P4 \\
\hline P25 & P14 & P3 \\
\hline P24 & P13 & P2 \\
\hline P23 & P12 & P1 \\
\hline
\end{tabular}

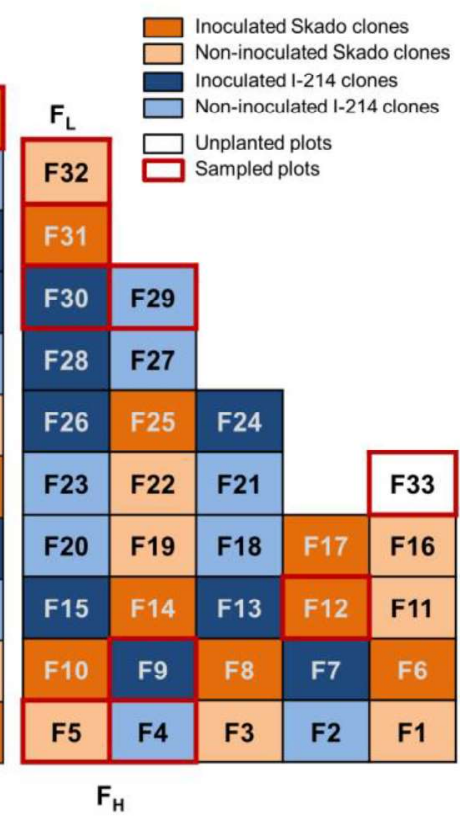

Fig. 1. a) Location of the two sites. b) Aerial view of the Pierrelaye site. c) Aerial view of the Fresnes site. d) Experimental designs of the field trials which indicate the sampled plots in yellow boxes. On the left, the experimental design of the Pierrelaye site. On the right, the experimental design of the Fresnes site. $\mathrm{P}_{\mathrm{L}}$ and $\mathrm{F}_{\mathrm{L}}$ refer to the least contaminated areas at the Pierrelaye and Fresnes sites, respectively whereas $\mathrm{P}_{\mathrm{H}}$ and $\mathrm{F}_{\mathrm{H}}$ refer to the most contaminated areas of the two sites.

\section{2-column fitting image}


a)

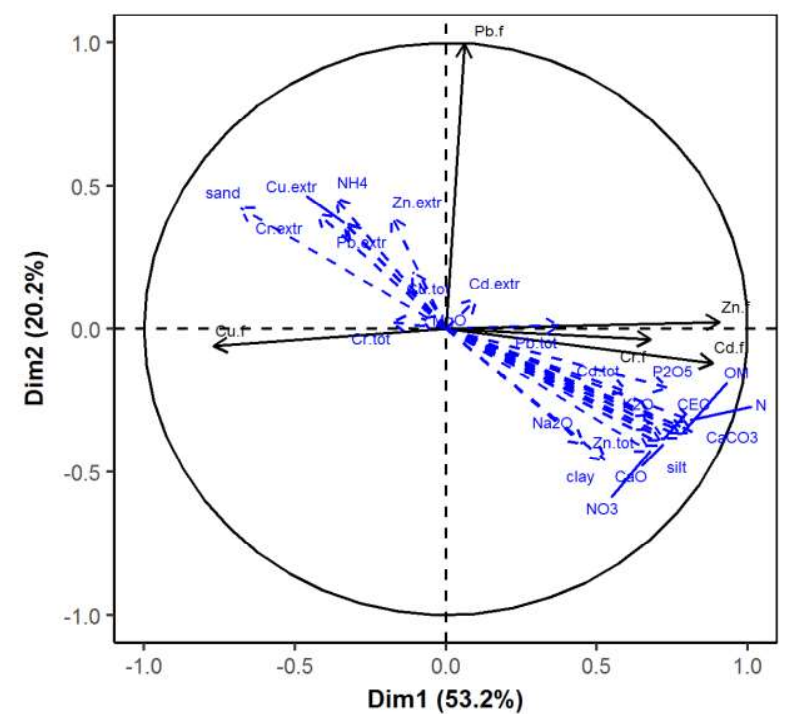

b)

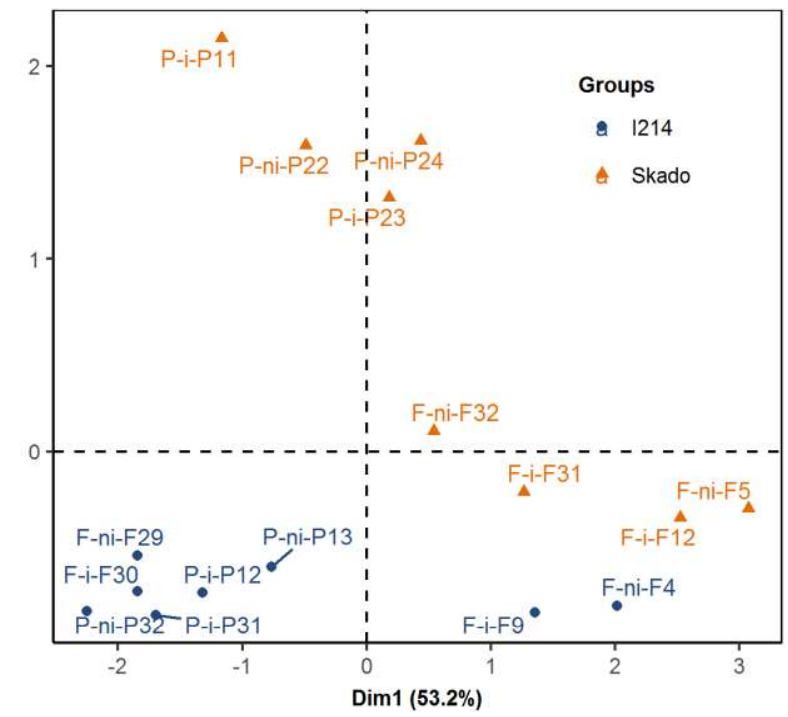

Fig. 2. a) Graph of active (black solid arrows; leaf metal contents) and supplementary variables (blue dotted arrows; soil physico-chemical parameters). b) Graph of individuals corresponding to inoculated ("-i") or noninoculated (“-ni") Skado and I-214, of Pierrelaye (P) and Fresnes (F) sites.

\section{2-column fitting image}



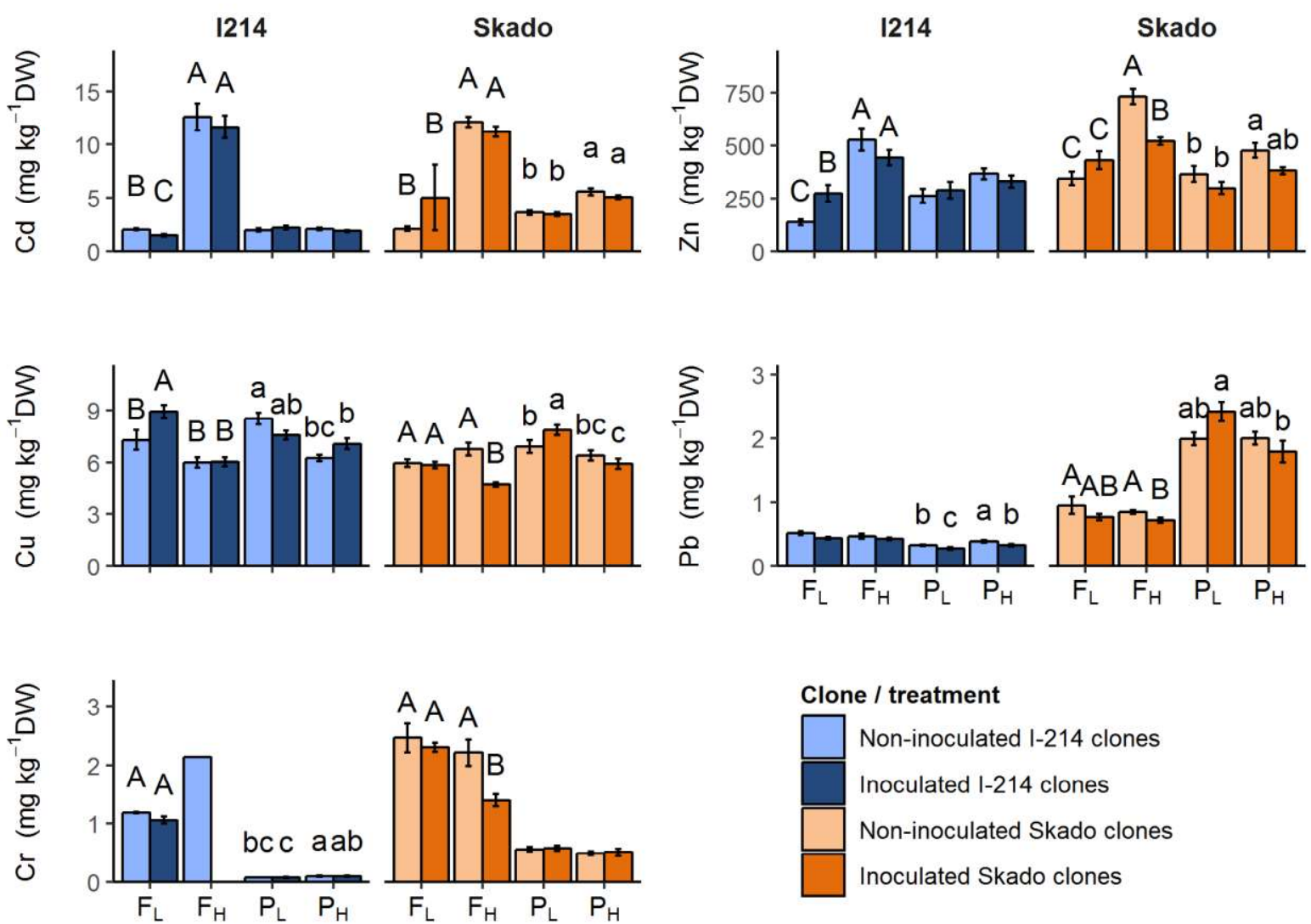

Fig. 3. Foliar concentrations of $\mathrm{Cd}, \mathrm{Zn}, \mathrm{Cu}, \mathrm{Pb}$ and $\mathrm{Cr}$ in Skado and $\mathrm{I}-214$ clones. $\mathrm{P}_{\mathrm{L}}$ and $\mathrm{F}_{\mathrm{L}}$ refer to the least contaminated areas at the Pierrelaye and Fresnes sites. respectively whereas $\mathrm{P}_{\mathrm{H}}$ and $\mathrm{F}_{\mathrm{H}}$ refer to the most contaminated areas of the two sites. Data are means \pm SE. Different letters indicate significant differences between the treatments for each site among each clone (Kruskal-Wallis test, $\mathrm{p}<0.05$ ). No letter indicates no difference. Data below the LQ are not represented (LQ $=1-2 \mathrm{mg} \mathrm{kg}^{-1}$ for $\mathrm{Cr}$ ). 

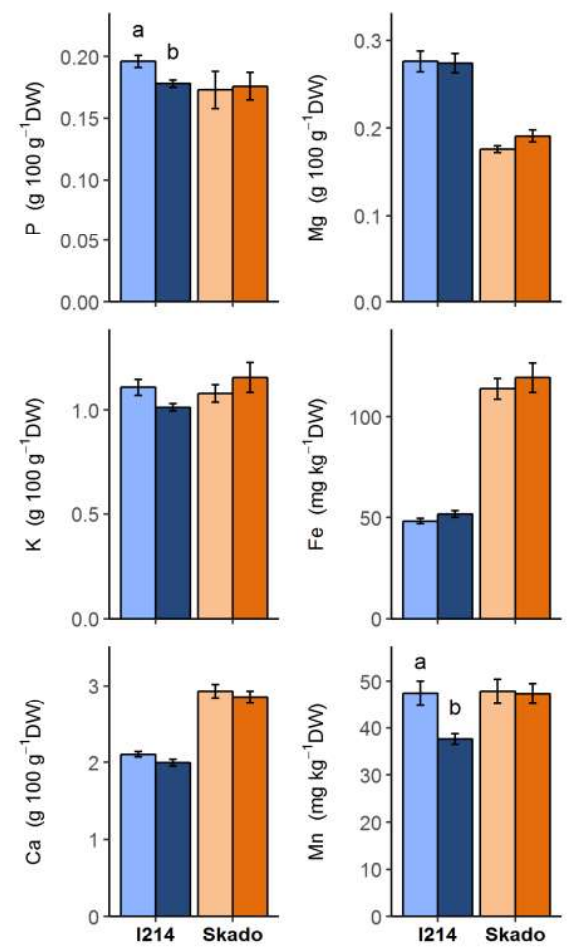

Clone / treatment

$$
\begin{aligned}
& \text { Non-inoculated I-214 clones } \\
& \text { Inoculated I-214 clones } \\
& \text { Non-inoculated Skado clones }
\end{aligned}
$$

Inoculated Skado clones

Fig. 4. Foliar concentrations of macronutrients $\mathrm{P}, \mathrm{K}, \mathrm{Ca}, \mathrm{Mg}, \mathrm{Fe}$ and $\mathrm{Mn}$ in Skado and I-214 clones. Data are means \pm SE. Different letters indicate significant differences between the treatments for each site, among each clone (Kruskal-Wallis test, $\mathrm{p}<0.05$ ). No letter indicates no difference.

\section{5-column fitting image}




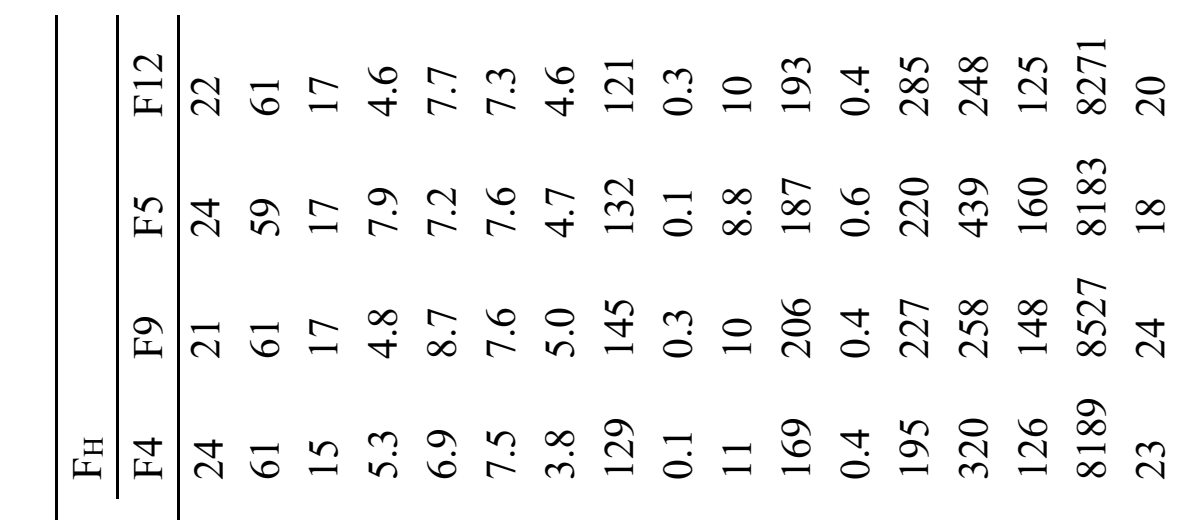

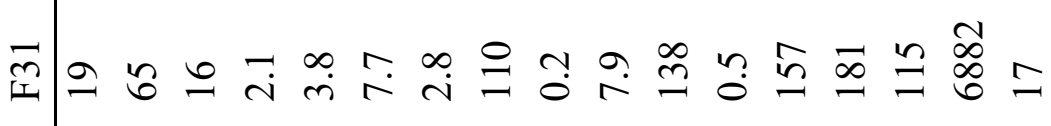

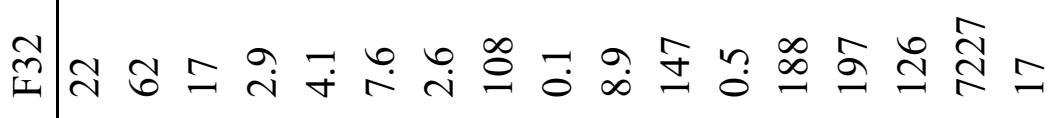

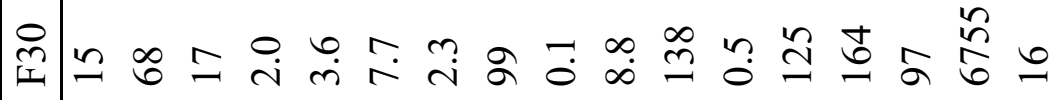

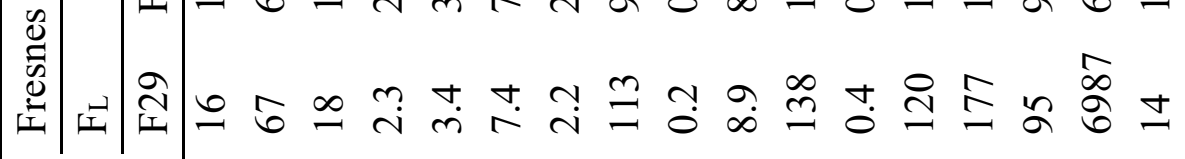

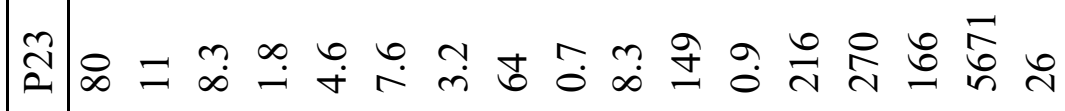

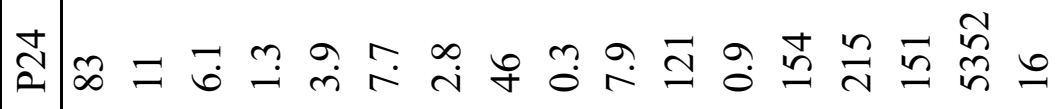

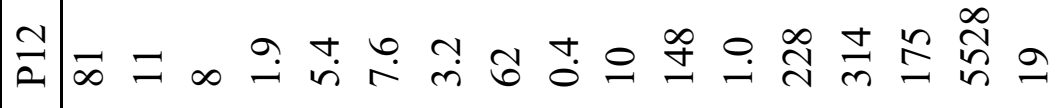

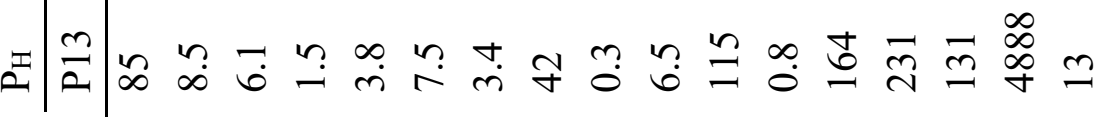

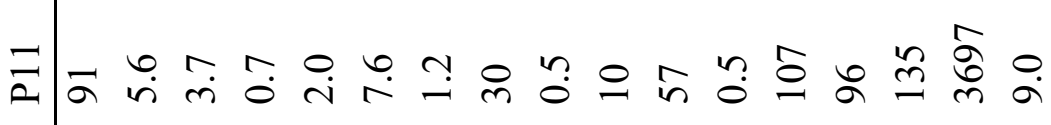

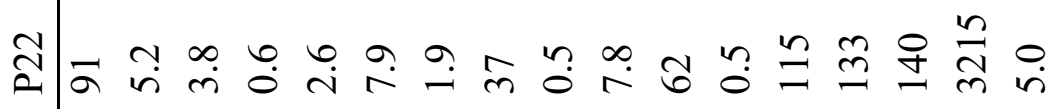

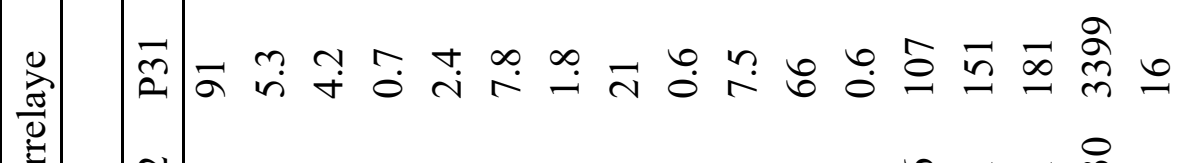
:

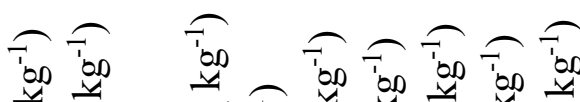

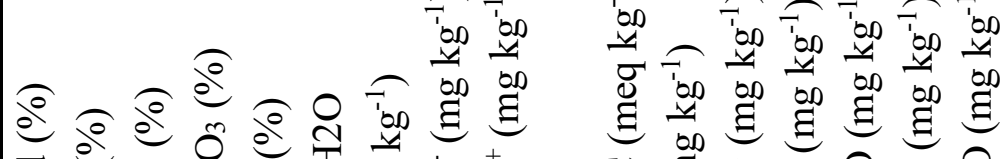

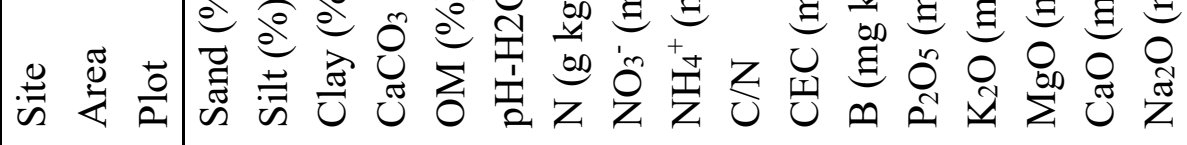




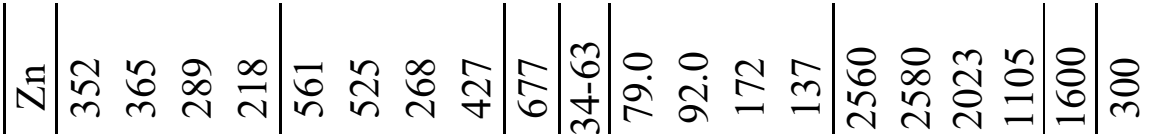

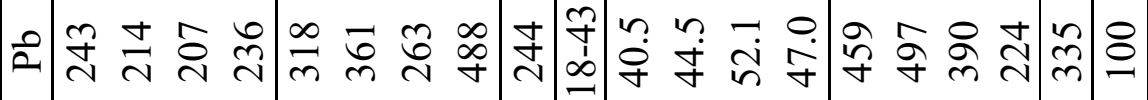

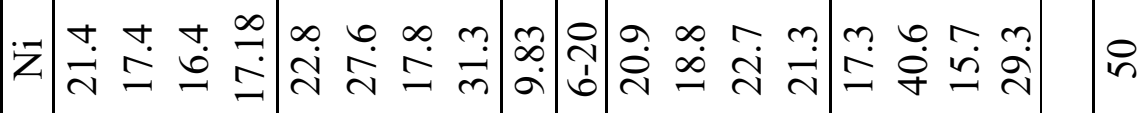

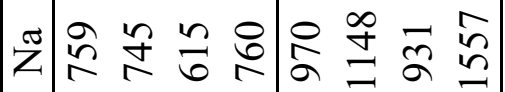

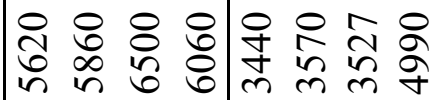

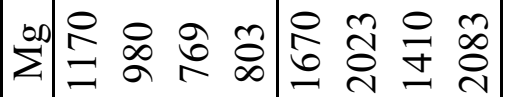

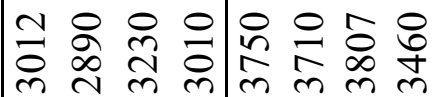

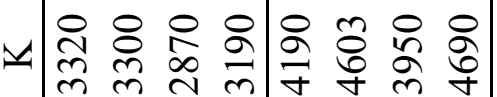

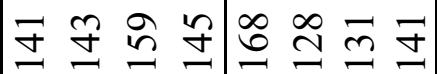

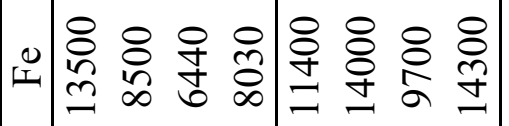

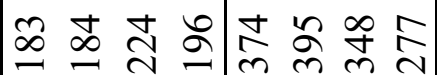
تี

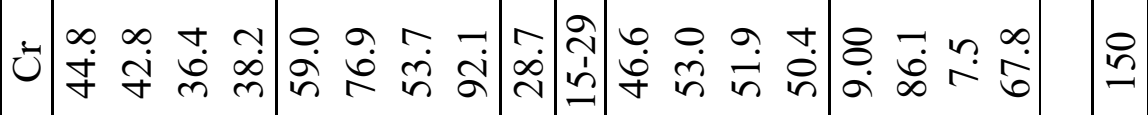

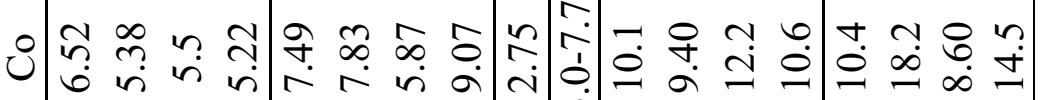

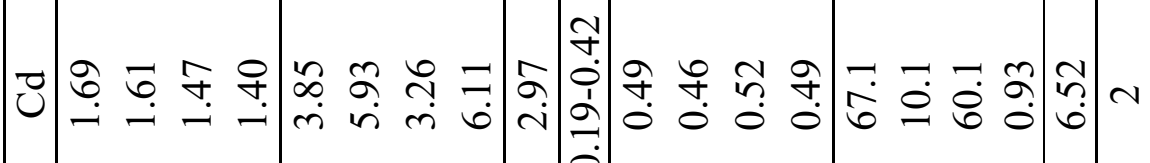
Uึ.

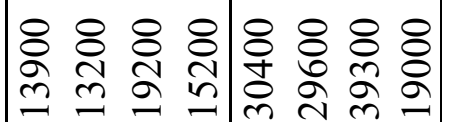

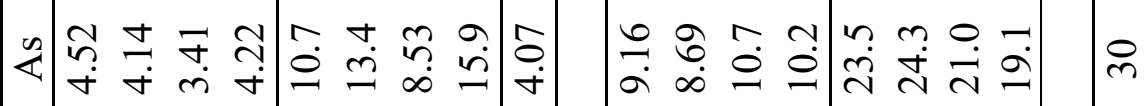

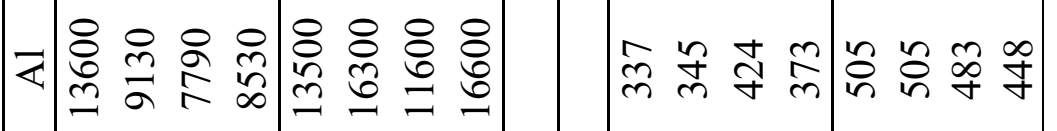

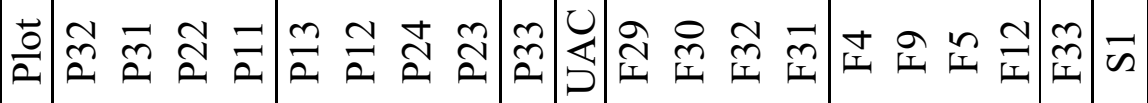

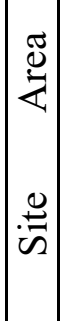

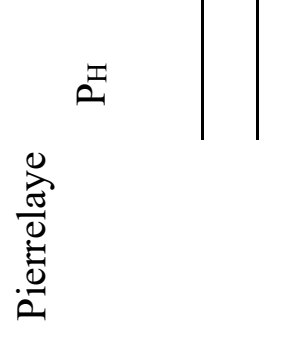
$|\underset{\mid}{\infty}|$ 


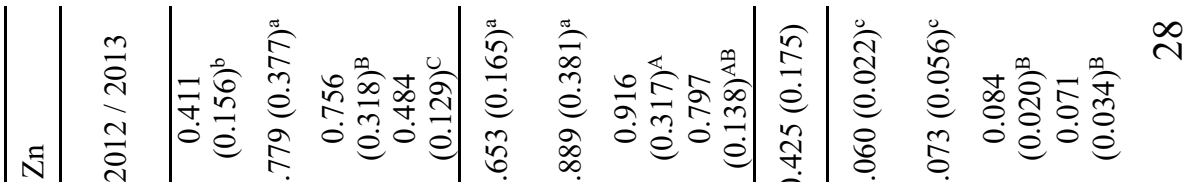

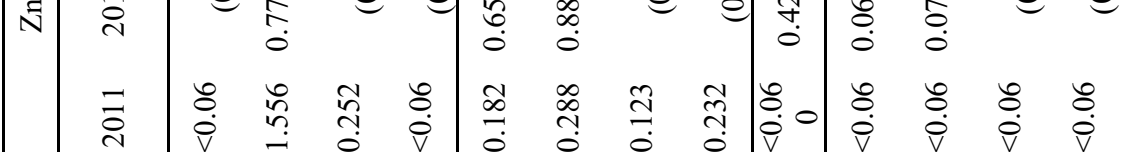

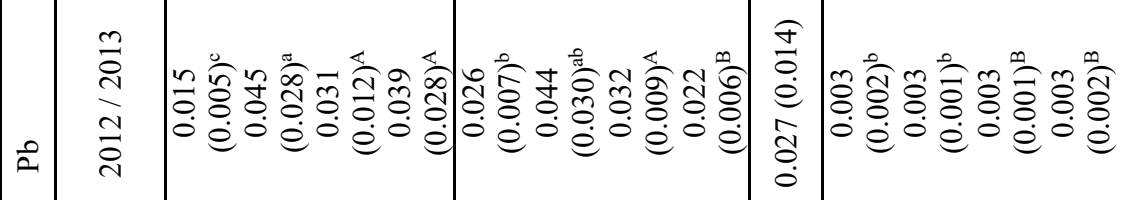

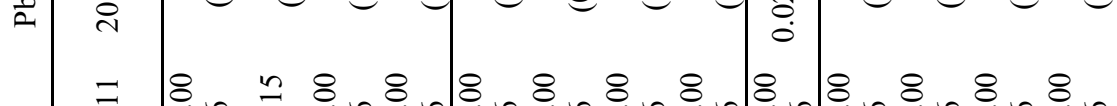

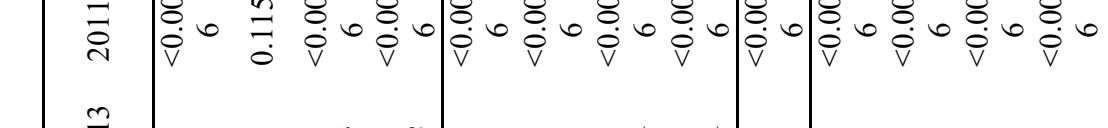

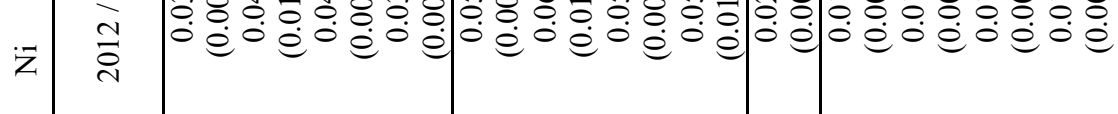

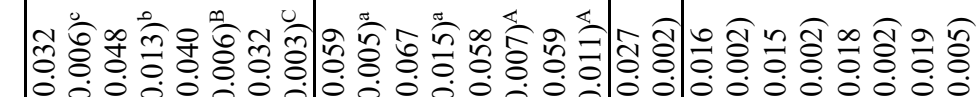

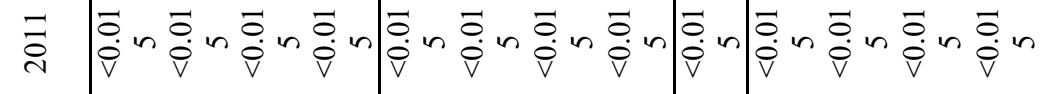

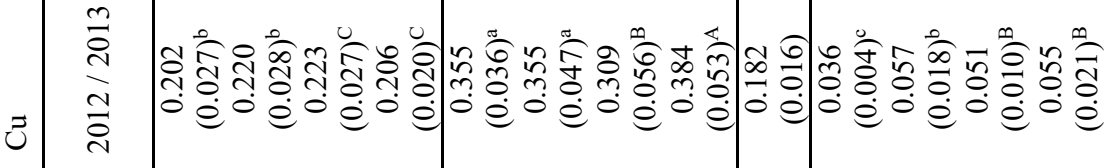

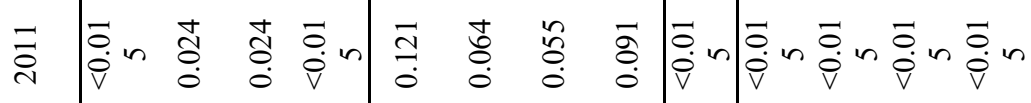

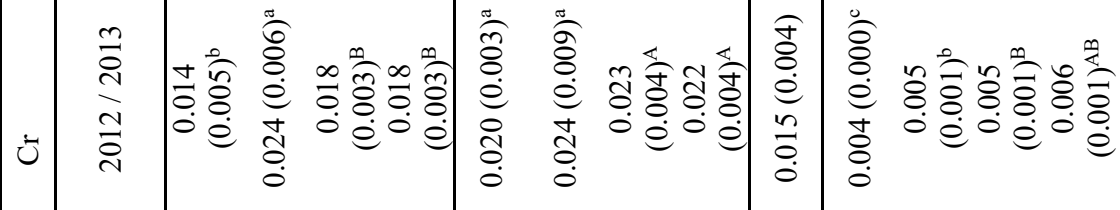

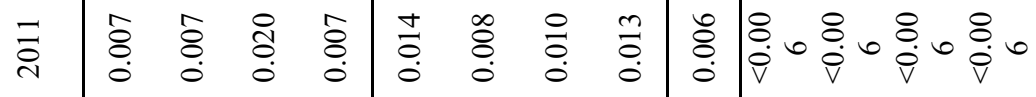

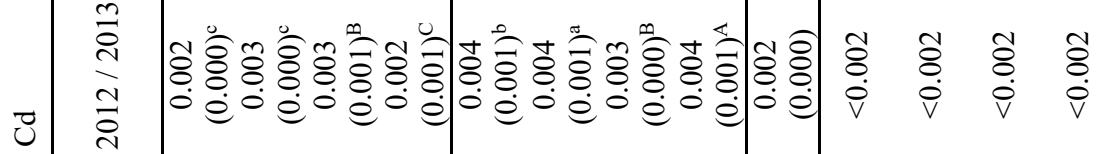

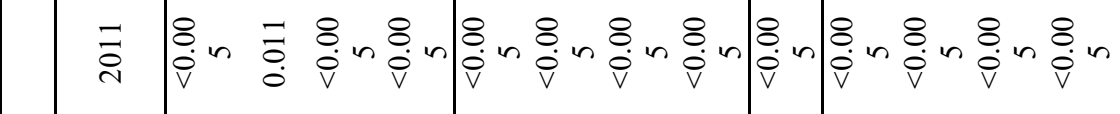

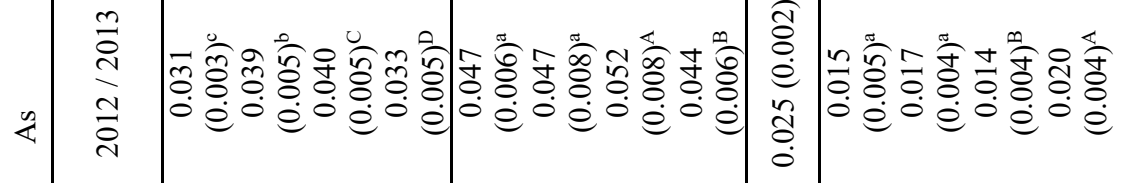

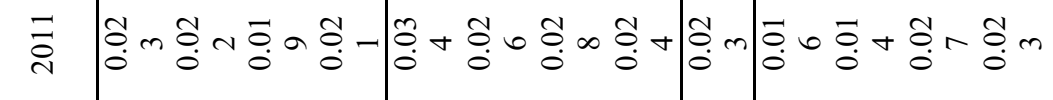

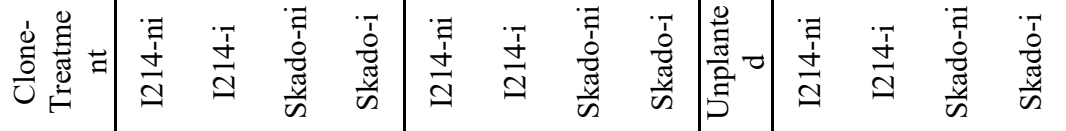

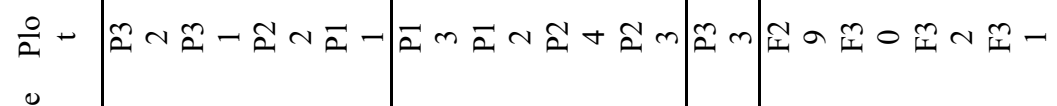
常

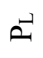
离。 


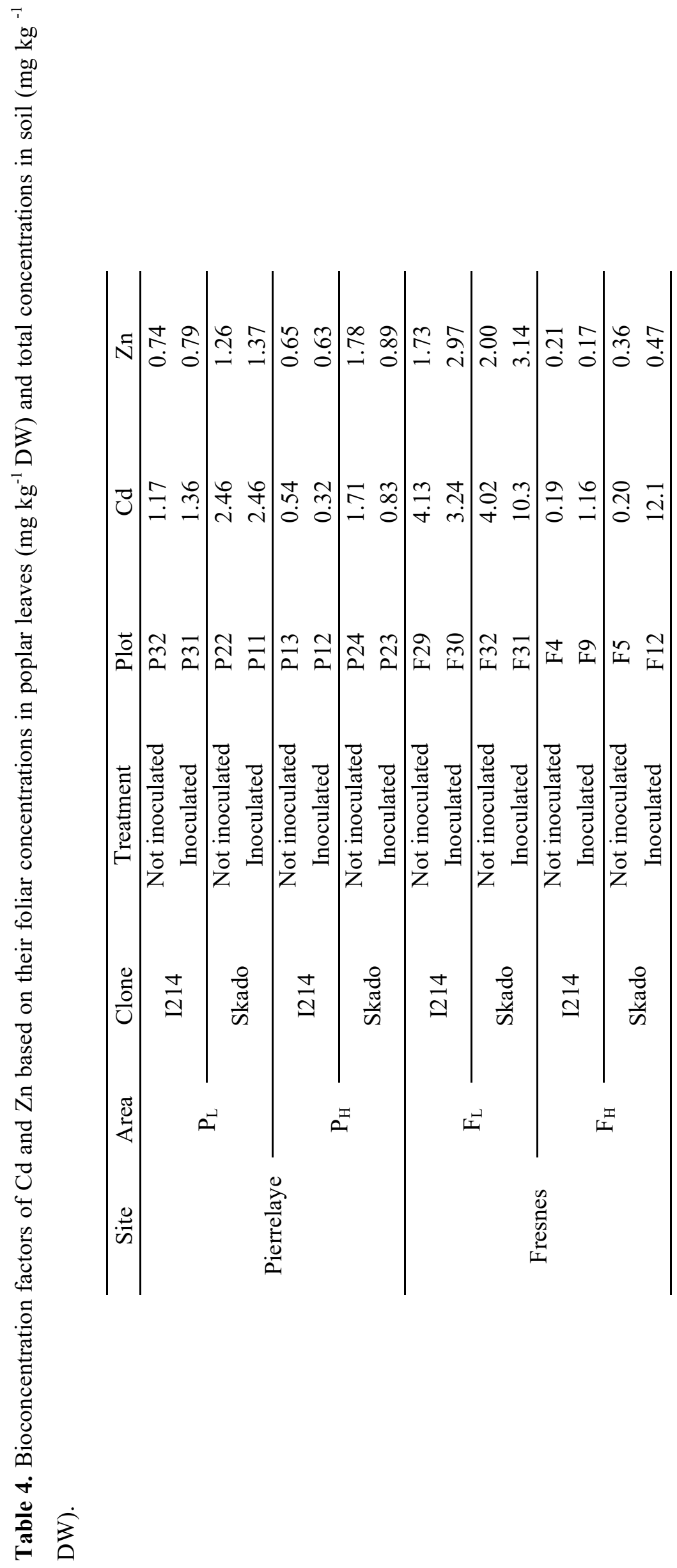

